\title{
Sequence architecture and sedimentary characteristics of a Middle Jurassic incised valley, western Sichuan depression, China
}

\author{
Jun-Long Liu ${ }^{1} \cdot$ Wei Yin ${ }^{1}$ You-Liang $\mathrm{Ji}^{2} \cdot$ Tian-Yun Wang ${ }^{3} \cdot$ Fu-Xiang Huang ${ }^{4} \cdot$ Hai-Yue Yu ${ }^{2}$. \\ Wen-Shu Li ${ }^{2}$
}

Received: 4 May 2016/Published online: 8 February 2018

(c) The Author(s) 2018. This article is an open access publication

\begin{abstract}
The Middle Jurassic Shaximiao Formation encompasses tens of meters of thick lowstand meandering valley (LMV) strata in the western Sichuan foreland basin. Ancient LMVs newly discovered in this area were further studied based on sequence stratigraphy and seismic sedimentology. The aim of the present study was to investigate the sedimentary characteristics, sequence architecture, and the controls on LMV deposition in this tectonically active basin using field survey data, seismic sections, seismic amplitude imaging, core description, and comprehensive application of drilling data. The results show the following: (1) Three regional sequence boundaries and two flooding surfaces were recognized, and the Shaximiao Formation was divided into two-third-order sequences and four systems tracts. (2) Three sedimentary facies associations were identified: incised valley-fill, tributary channel, and overbank facies. Incised valleys are 5-17 km wide, 20-60 m deep and traceable for $120 \mathrm{~km}$ along their axes. (3) In the downstream segment, the role of tectonism gradually diminishes, and periodic base-level changes control the form and evolution of the incised valleys. Three types of LMVs-A1, A2, and A3 - developed with changes in base level (lake level); of these types, the base level of the A3 LMV was likely the lowest.
\end{abstract}

Keywords Sequence architecture $\cdot$ Sedimentary characteristic $\cdot$ Lowstand meandering valley $\cdot$ Western Sichuan depression · Shaximiao Formation

\section{Introduction}

Incised valleys have been widely discussed in terms of traditional depositional models (Vail et al. 1977; Posamentier and Vail 1988; Van Wagoner et al. 1988; Zaitlin et al. 1994; Willis 1997; Veiga et al. 2002; Catuneanu 2006; Catuneanu et al. 2009); however, detailed analysis of

Edited by Jie Hao

You-Liang Ji

ji_youliang@sina.com

1 Sinopec Exploration \& Production Research Institute, Beijing 100083, China

2 State Key Laboratory of Petroleum Resources and Prospecting, China University of Petroleum, Beijing 102249, China

3 Xinxing Geophysical Department, Bureau of Geophysical Prospecting, CNPC, Zhuozhou 072751, Hebei, China

4 Daqing Oil Company, CNPC, Daqing 163000, Heilongjiang, China the sequence architecture and sedimentary characteristics of incised valleys based on seismic data has rarely been attempted in the past. In addition, previous studies of the form and evolution of incised valleys have primarily focused on Quaternary valleys (Reynaud et al. 1999; Nordfjord et al. 2006; Bettis III et al. 2008; Green 2009; Lin et al. 2010; Paquet et al. 2010; Lévy et al. 2012; KeenZebert et al. 2013) rather than on ancient valleys.

The Jurassic Shaximiao $\left(\mathrm{J}_{2} s\right)$ Formation was deposited during a stable tectonic period in the western Sichuan foreland basin. According to previous studies, its sedimentary environment is characterized mainly by fluvialdeltaic facies (Li et al. 2007, 2012; Wang et al. 2007, 2010; Zhu 2009; An 2011; Li 2011; Yang et al. 2011; Qian et al. 2012). Through integrating previous interpretations with applications of sequence stratigraphy and seismic sedimentology, researchers identified lowstand meandering valleys (LMVs) in this area (Zhu 2009; Li 2011; Qian et al. 2012). Previous studies have described the distribution patterns of the sedimentary environments and depositional facies of the Shaximiao Formation in this area; these 
studies have contributed to exploration of local gas fields. Nonetheless, because of the lack of data (i.e., three-dimensional (3D) seismic data did not cover the entire study area in early studies), the following problems remain. (1) Horizontal 3D seismic slices reveal the abnormality of infilled incised valleys, which were approximately $10 \mathrm{~km}$ in width during the early depositional periods of both members of the formation; this finding may contradict the interpretation that the Shaximiao Formation was deposited by classical meandering rivers. (2) The base-level changes that control the sediment infilling of incised meandering valleys have not yet been extensively investigated in a rejuvenated foreland basin. Therefore, further investigations are needed to identify the sequence architecture and sedimentary characteristics of these LMVs.

Using an integrated dataset from seismic profiles, outcrops, well logs, and cores, this study aims: (1) to examine the sequence architecture of the LMVs; (2) to identify the sedimentary characteristics of the LMVs; and (3) to study the spatial and temporal evolution of the LMVs. This research not only deepens insight into ancient incised valleys in 3D by studying the nature of the LMVs, but also provides insight for gas exploration and exploitation in the study area, as $\mathrm{J}_{2} s$ sandbodies are important tight sandstone reservoirs in the subsurface (Luo and Chen 2004; Zhu 2009; Wang et al. 2010; An 2011; Li et al. 2012; Qian et al. 2012).

\section{Geological setting}

\subsection{Geographic location}

The western Sichuan depression is located in the western part of the Sichuan Basin, surrounded by the Longmen Mountain Thrust Belt (LMTB) and the Longquan Mountain foreland Uplift Belt (LMFUB) (Fig. 1; Yang et al. 2005, 2016; Jiang et al. 2007; Li et al. 2009, 2011; Luo and Li 2009; Huang et al. 2010; An et al. 2011; Liu et al. 2011). The study area is located in the middle of the western Sichuan depression. This area, which has a total area of $1.1 \times 10^{4} \mathrm{~km}^{2}$, is confined by Dujiangyan City to the west, Huluxi City to the east, An'xian City to the north and Chengdu City to the south.

\subsection{Tectonic evolution of the foreland basin}

The western Sichuan depression transformed from a peripheral foreland basin in the Late Triassic into a rejuvenated foreland basin in the Middle Jurassic; this transformation is attributed to the subduction of the Yangtze Block (Fig. 2; Wang and Meng 2008; Zheng et al. 2008; Zou et al. 2013; Yu et al. 2016; Ye et al. 2017). During the depositional period of the Shaximiao Formation, the LMTB was relatively static, whereas the Micang-Daba Mountains Tectonic Zone (MDMTZ; Fig. 1) was more active because of the "scissor-type" subduction of the Yangtze Block (Deng 2007; Jin et al. 2008; Liu et al. 2010; Yuan et al. 2012; Bian et al. 2015). As a result, the foredeep depression was transferred from the northern section of the Longmen Mountains to the Micang-Daba Mountain front (Chen et al. 2008; Luo et al. 2011). The study area, which is in the middle part of the western Sichuan depression, is located far from the MDMTZ and was tectonically stable during the depositional period of the Shaximiao Formation; consequently, its thickness changes laterally only slightly in the study area (Fig. 2).

\subsection{Sedimentary environment and stratigraphic characteristics}

The Ganzi-Aba Indosinian orogenic belt and the Qinling orogenic belt formed at the end of the Late Triassic; as a result, the climate of the Sichuan Basin was transformed from warm and humid to hot and arid, thereby facilitating the deposition of Jurassic red beds in the study area (Yong et al. 2008; An et al. 2011). Controlled by tectonic activity, large amounts of terrestrial debris were transported from the mountains at the basin margin, and a succession of fluvial and lacustrine red clastic rocks was deposited under semiarid to arid climatic conditions (Li et al. 2009; Zhu et al. 2010). During this period, the paleocurrent direction was mainly from northeast to southwest (Figs. 1, 3). The net sandstone percentage (NSP) and mean grain size (MGS) data were obtained from boreholes in the upstream area, $\mathrm{A}, \mathrm{B}$ and $\mathrm{C}$, and downstream, $\mathrm{A}^{\prime}, \mathrm{B}^{\prime}$ and $\mathrm{C}^{\prime}$. The statistics of these data (Fig. 3) indicate that both the NSP and MGS values decrease in the downstream direction.

The Shaximiao Formation (Fig. 4), the target stratigraphic interval, overlies the Qianfoya Formation and underlies the Suining Formation (Chen et al. 2011). The Shaximiao Formation (Fig. 4) is subdivided vertically into the Lower Shaximiao $\left(\mathrm{J}_{2} s^{1}\right)$ Member and the Upper Shaximiao $\left(\mathrm{J}_{2} s^{2}\right)$ Member by the top of the Conchostraca shale or the bottom of the Jiaxiangzhai Sandstone. Twelve sub-members can be further divided.

The Shaximiao Formation is composed of several interbedded layers of gray to grayish-purple, thick-bedded, blocky, fine- to medium-grained subarkose, arkose, purple siltstone, and mudstone; each of these components exhibits variable thickness (Fig. 4; Wang et al. 2001; Lin 2009). The $\mathrm{J}_{2} s^{1}$ Member consists of two to four sets of superimposed gray to grayish-purple, thick-bedded, fine- to medium-grained subarkose, arkose, purple siltstone, and mudstone; each layer typically exhibits a thickness of 100-300 m and occasionally 400-500 m. The $\mathrm{J}_{2} s^{1}$ Member 


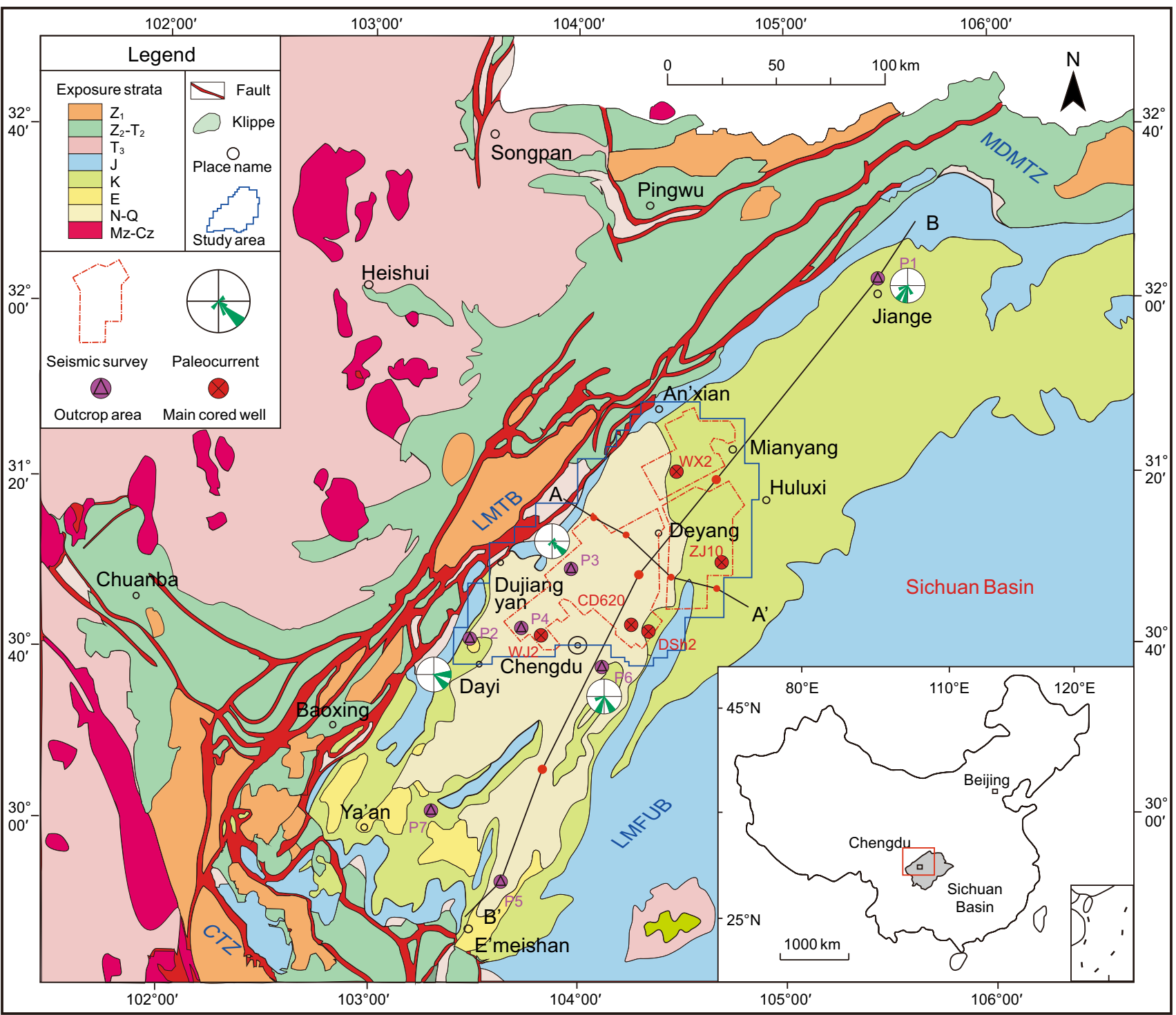

Fig. 1 Tectonic setting and simplified geological map of the middle part of the western Sichuan depression (modified after Li et al. 2008). Abbreviations include the Longmen Mountain Thrust Belt (LMTB), the Longquan Mountain Foreland Uplift Belt (LMFUB), the Chuandian Tectonic Zone (CTZ), and the Micang-Daba Mountains Tectonic Zone (MDMTZ). The study area in the western part of the Sichuan Basin is outlined. The locations of cross section BB' in Fig. 5 and cross section $\mathrm{AA}^{\prime}$ in Fig. 6 are marked. The location of cored well

also contains bivalve fossils, such as Ferganoconcha estheriaeformis, Pseudocardinia kweichonensis, P. hupehensis, P. elliptica, and P. ovalis. This member also contains organisms belonging to the Conchostraca, such as Euestheria ziliujingensis, E. complanata, E. cf. haifangouensis, and E. yanjiawanensis, and fragmentary phytolites, such as Podozamites sp., Equisetites sp., and Otozamites sp. All of these fossils were preserved in the Conchostraca shale and are Middle Jurassic in age (Fig. 4). The $\mathrm{J}_{2} s^{2}$ Member varies greatly in lithology and thickness
WJ2 in Fig. 8 is shown in the northwest of the study area. P1-7 are typical outcrops shown in Figs. 5, 7, and 9, including GuangyuanJiange (section P1), Dayi (section P2), Pengzhou (section P3), Chongzhou (section P4), E'mei (section P5), Longquanyi (section P6), and Yuelanshan (section P7). The cored wells WX2, CD620, ZJ10, and DSh2 represented in Fig. 10 are shown in the east of the study area. City names (capital and lower case letters) are given for reference

(400-2000 m); its thickness increases from west to east and from south to north, with the thickest succession found at the Micang-Daba Mountain front. The lower part of this member contains gray mudstones that are typically interlayered with abundant beds of thin marls and clam fossils, whereas the upper part contains variegated mudstones with calcareous concretions.

The ancient $\mathrm{J}_{2}$ s lake has been studied sedimentologically and paleoclimatologically (Wang et al. 2001; Wang and Xu 2001; Cao 2007; Wang et al. 2008; Qian et al. 2012; Zhang 


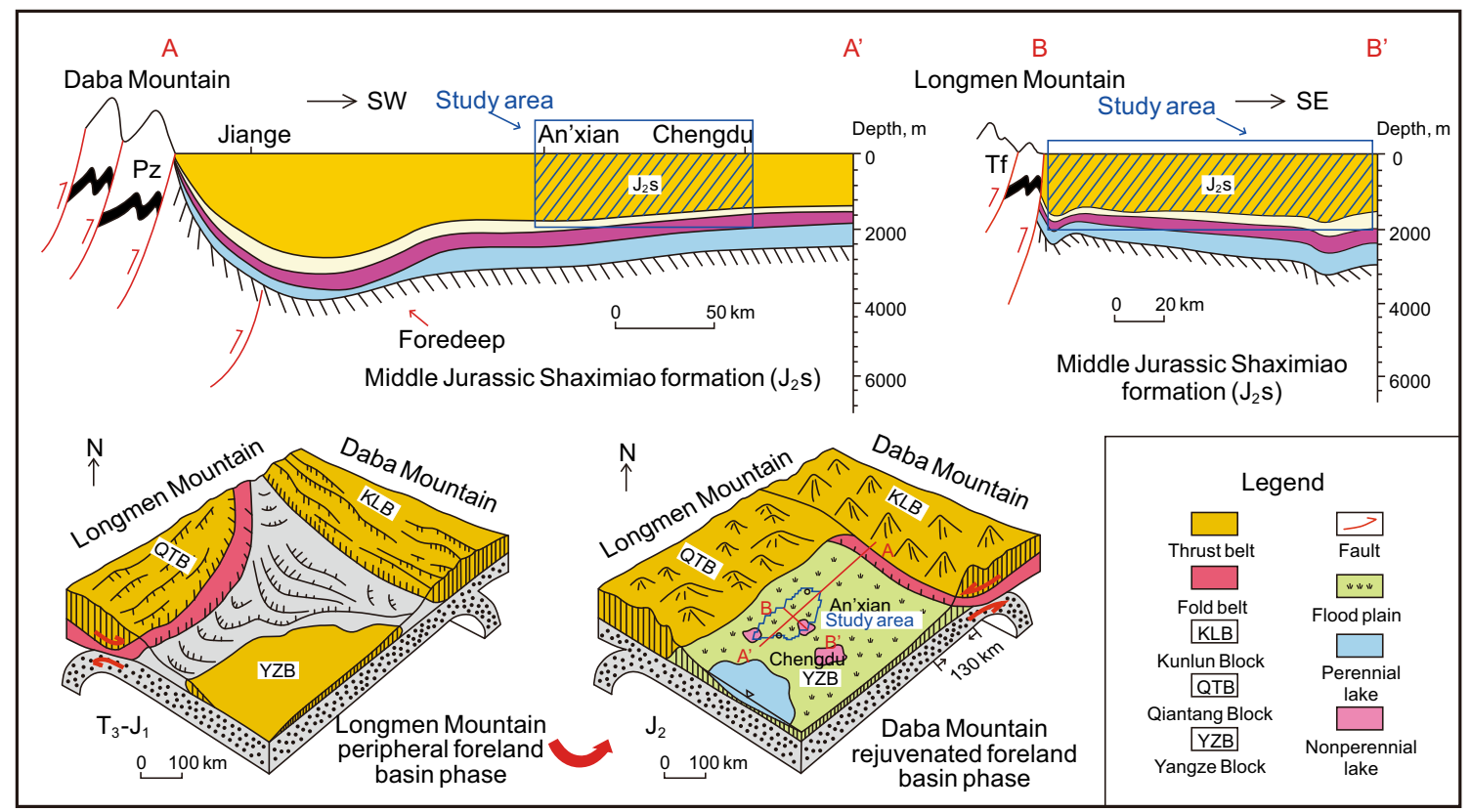

Fig. 2 Middle Jurassic tectono-stratigraphic characteristics of the western Sichuan depression. Different phases of foreland basin evolution in the Late Triassic, Early Jurassic, and Middle Jurassic associated with different stress directions, modified after Zheng et al. (2008). The study area is located approximately $130 \mathrm{~km}$ from the
Daba Mountains; therefore, it was not uplifted by thrusting and steadily subsided during the depositional period of the Middle Jurassic Shaximiao Formation. Abbreviations include Kunlun Block (KLB), Qiantang Block (QTB), and Yangtze Block (YZB)
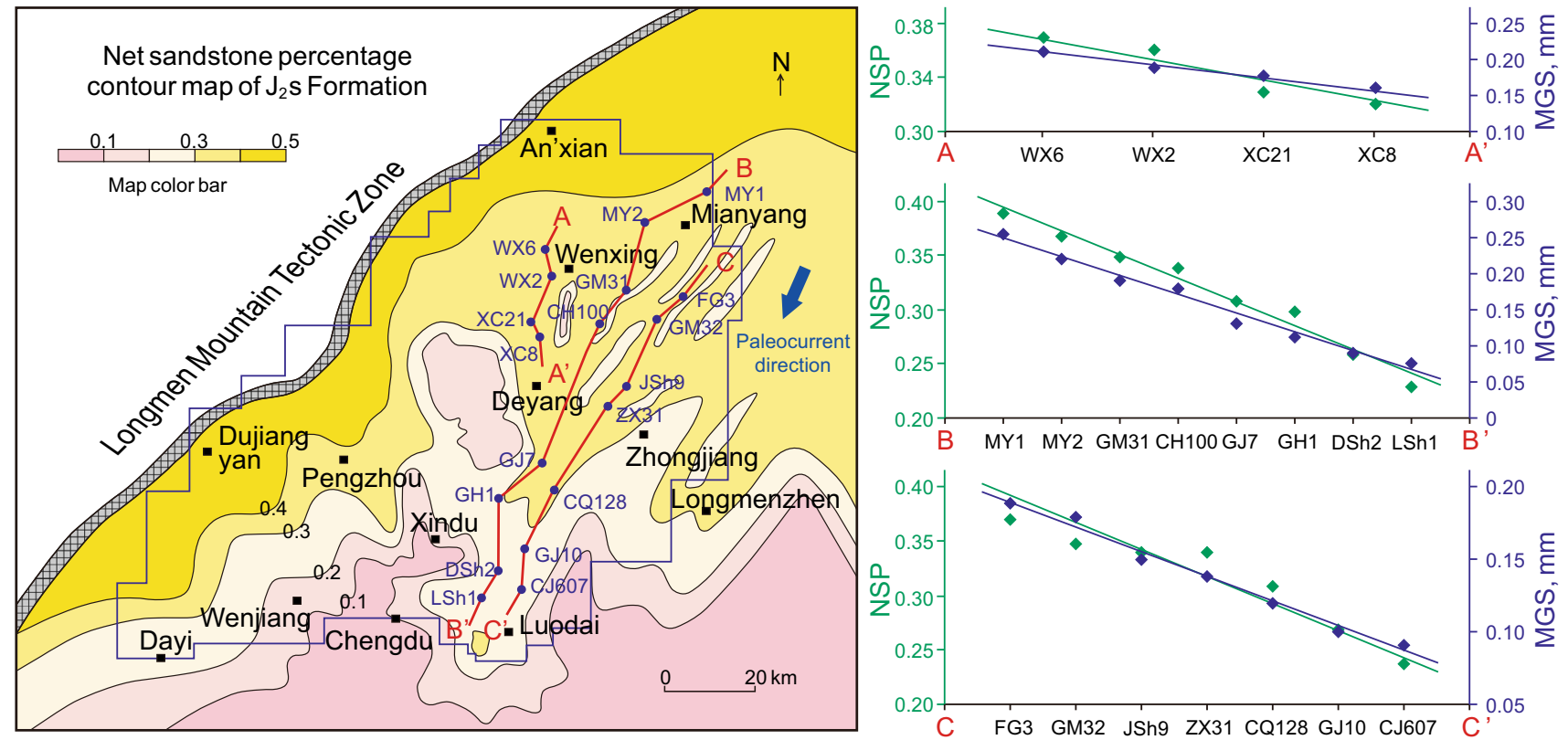

Fig. 3 Net sandstone percentage contour map of the $\mathrm{J}_{2} s$ Formation showing the paleocurrent direction. $\mathrm{AA}^{\prime}, \mathrm{BB}^{\prime}$, and $\mathrm{CC}^{\prime}$ are oriented from upstream to downstream. NSP: net sandstone percentage; MGS: mean grain size

2013). Two kinds of paleolakes have been identified in the study area: perennial and non-perennial lakes (Fig. 2; Wang et al. 2008; An 2011; Qian et al. 2012). The nonperennial $\mathrm{J}_{2} s$ lakes, which were influenced by seasonal climatic changes, developed on the floodplain (Cao 2007;
An 2011; Qian et al. 2012). When floods occurred, the floodplain was partially inundated, and the non-perennial lakes were interconnected. When the floods receded, the water evaporated because of the hot weather, and these non-perennial lakes were separated again. The non- 




Fig. 4 Stratigraphic characteristics and foredeep migration of the western Sichuan depression (modified after Chen et al., 2008). The colored strata are the target stratigraphic interval. The Jiaxiangzhai

perennial lakes are presumed to have been a typical sedimentary environment during this period (An 2011; Qian et al. 2012; Qian 2013), which may indicate an arid climate and rapid changes in lake level.
Sandstone (Jiaxiangzhai ST.), Guankou Sandstone (Guankou ST.) and Conchostraca shale are marked beside the lithologic section

\section{Methods}

\subsection{Data and materials}

To study the sequence architecture and sedimentary characteristics of the LMVs, we used outcrop data, seismic datasets, well drilling data, and cores. In the Shaximiao 
Formation, seven representative outcrop profiles that are well exposed in the western Sichuan depression were selected. These profiles included the Guangyuan-Jiange (section P1 in Fig. 1), Dayi (section P2 in Fig. 1), Pengzhou (section P3 in Fig. 1), Chongzhou (section P4 in Fig. 1), E'mei (section P5 in Fig. 1), Longquanyi (section P6 in Fig. 1), and Yuelanshan (section P7 in Fig. 1) sites. The Guangyuan-Jiange and Dayi profiles display the most typical valley infills of the Shaximiao Formation. Three merged 3D seismic volume datasets covered the Zhongjiang-Huilong (southeast of the study area in Fig. 1), Mianyang (northeast of the study area in Fig. 1), and Chengdu (west of the study area in Fig. 1) areas, of which the LMVs in the first area are the most developed. The 3D seismic data used in this study cover a total areal extent of approximately $8500 \mathrm{~km}^{2}$, which is $80 \%$ of the study area. We also used drilling data, including logging and core analysis data from 99 exploratory wells that together cover every tectonic section of the western Sichuan depression; among these wells, 19 were cored.

\subsection{Research methods}

\subsubsection{Depositional facies and sequence analysis of outcrop profiles}

To investigate the sedimentary characteristics and sequence architecture of the LMVs, we analyzed the representative outcrop profiles, which displayed the size and distribution patterns of meandering valleys. The sequence architecture, architectural elements, vertical stacking patterns, and intersecting orders of the LMVs were analyzed. Paleocurrent directions on outcrop profiles were identified based on analysis of tens of samples.

To provide a general overview of the sequence stratigraphy, two outcrops (sections P1 and P7 in Fig. 1) located at the basin margin were correlated with three boreholes in the center of the basin (BB' in Fig. 1). The tectonic setting of the study area was an extensive foreland basin, and baselevel (lake-level) rise and fall strongly controlled the form and evolution of the LMVs; therefore, Catuneanu's depositional sequence scheme has been applied in this area. In addition, lithofacies were identified from the outcrops.

\subsubsection{Detailed description of 3D geometry based on combined borehole-seismic data}

The China Petroleum and Chemical Corporation (SINOPEC) acquired 3D seismic datasets from several regions of the interior part of the western Sichuan depression, where outcrops are rare. In this study, these raw data were used to reveal the 3D geometry of the LMVs of the Shaximiao Formation.
The main technology used in this study comprised synthetic seismograms, seismic profiles, and the rootmean-square (RMS) amplitude attribute generated using the Landmark software. Synthetic seismograms were used to link borehole and seismic data. Based on these data, we interpreted the seismic profiles to describe the LMVs of the Shaximiao Formation, including three sequence boundaries, two flooding surfaces and several parasequence boundaries. Attributes such as RMS amplitudes, average intensities of reflection, and arc lengths were then obtained from the 3D seismic volume datasets. Among these attributes, the RMS amplitude showed a clear response to the $\mathrm{J}_{2} \mathrm{~S}$ LMVs; therefore, this attribute was investigated extensively in the study. Moreover, a sequence-stratigraphic framework was established based on combined borehole and seismic data, and seismic and depositional facies in the established framework were analyzed. All of these investigations contribute to detailed analysis of the lateral and vertical distribution patterns of meandering valleys.

\subsubsection{Core facies and vertical section analysis}

Core data, which like outcrop data provide crucial firsthand information about meandering valleys, are conventionally used to analyze depositional facies based on recognition of the presented lithology and sedimentary structures. In this study, cores from 19 typical wells were observed and analyzed. Vertical sedimentary sections of LMVs were constructed and used as references to identify sedimentary microfacies and to investigate sedimentary patterns and evolution in similar areas.

\section{Results}

\subsection{Sequence stratigraphy of the Shaximiao Formation}

Based on Catuneanu's depositional sequence scheme (Catuneanu 2006), three regional sequence boundaries (SB) and two flooding surfaces (FS) were recognized, and the Shaximiao Formation was divided into two-third-order sequences (SQ1 and SQ2) with four systems tracts and several parasequences (Table 1, Fig. 5).

\subsubsection{Sequence-stratigraphic interfaces}

$\mathrm{SB} 1$ is a regional unconformity (third order). The Guankou Sandstone, which is a clear marker of SB1, is approximately $65 \mathrm{~m}$ thick at the Daba Mountain front (Fig. 5a) and tapers to the west and south. SB2 is a large-scale erosional discontinuity (third order) caused by environmental 
Table 1 Sequence-stratigraphic classification and characteristics of the Shaximiao Formation in the middle part of the western Sichuan depression

\begin{tabular}{|c|c|c|c|c|c|}
\hline Sequence & Systems tract & Sequence characteristics & Stratigraphic pattern & $\begin{array}{l}\text { Sequence } \\
\text { unit } \\
\text { boundary }\end{array}$ & $\begin{array}{l}\text { Seismic } \\
\text { reflection } \\
\text { surface }\end{array}$ \\
\hline & & & & SB3 & $\mathrm{T}_{2}$ \\
\hline \multirow{5}{*}{ SQ2 } & $\mathrm{HST}+\mathrm{FSST}$ & $\begin{array}{l}\text { Base level falling slowly, } \\
\text { accommodation (A) declining } \\
\text { gradually, progradation seaward }\end{array}$ & $\begin{array}{l}\text { Progradational pattern in the early stage, } \\
\text { progradational-retrogradational pattern in } \\
\text { the late stage }\end{array}$ & & \\
\hline & & & & $\mathrm{FS} 2$ & $\mathrm{~T}_{31}$ \\
\hline & $\mathrm{LST}+\mathrm{TST}$ & $\begin{array}{l}\text { Base level rising slowly, A increasing } \\
\text { gradually, retrogradation seaward }\end{array}$ & $\begin{array}{l}\text { Aggradational-retrogradational pattern in } \\
\text { the early stage, retrogradational pattern in } \\
\text { the late stage }\end{array}$ & & \\
\hline & & & & SB2 & $\mathrm{T}_{3}$ \\
\hline & $\mathrm{HST}+\mathrm{FSST}$ & $\begin{array}{l}\text { Base level falling rapidly, } \mathrm{A} \text { is } \\
\text { insufficient, sedimentary discontinuity }\end{array}$ & Progradational pattern & & \\
\hline \multirow[t]{3}{*}{ SQ1 } & & & & FS1 & $\mathrm{T}_{41}$ \\
\hline & $\mathrm{LST}+\mathrm{TST}$ & $\begin{array}{l}\text { Base level rising slowly, A increasing } \\
\text { gradually, retrogradation seaward }\end{array}$ & $\begin{array}{l}\text { Aggradational-retrogradational pattern in } \\
\text { the early stage, progradational pattern in } \\
\text { the late stage }\end{array}$ & & \\
\hline & & & & SB1 & $\mathrm{T}_{4}$ \\
\hline
\end{tabular}

LST lowstand systems tract, TST transgressive systems tract, HST highstand systems tract, FSST falling-stage systems tract (Catuneanu 2006)

changes. The Jiaxiangzhai Sandstone is the typical marker for SB2; it is approximately $75 \mathrm{~m}$ thick at the Daba Mountain front (Fig. 5c) and tapers to the west and south. SB3 is a regional unconformity (second order) related to basin-scale tectonic events. At the E'mei outcrop (Fig. 5d), SB3 corresponds to a basal erosional surface. In addition, truncation reflectors in the seismic profiles, which are also important evidence of sequence boundaries, were identified at the top of sequences SQ1 and SQ2 (Fig. 6).

FS1 and FS2 correspond to two flooding events in the study area. FS1 was the maximum flooding surface (MFS) during the Middle Jurassic, which corresponds to the Conchostraca shale. The Conchostraca shale is embedded in the upper part of SQ1 and is a widely developed and easily recognizable MFS in the Sichuan Basin (Fig. 4). This shale (Fig. 5b) divides SQ1 into transgressive (lowstand) and highstand systems tracts, which present an asymmetric "dual structural" pattern. The characteristics of these sequences and systems tracts are described below.

\subsubsection{Sequence architecture}

\subsubsection{Sequence 1 (SQ1)}

\section{Description}

SQ1 comprises the $\mathrm{J}_{2} s^{1}$ Member (Table 1; Figs. 5, 6). SQ1 thickens progressively from northeast to southwest (Figs. 5, 6). Its thickness is generally less than $150 \mathrm{~m}$ in the southwest and reaches $500 \mathrm{~m}$ in the northeast. SQ1 pinches out near Dujiangyan and Dayi at the Longmen Mountain front where it is less than $100 \mathrm{~m}$ thick and composed mainly of alluvial conglomerates.

2. Interpretation

During the SQ1 depositional period, the Sichuan Basin transformed into a rejuvenated foreland basin, the MicangDaba Mountains were intensively uplifted, and a corresponding piedmont depression formed in the western part of the western Sichuan depression. Under arid climatic conditions, predominantly fluvial systems developed in the study area during SQ1 (An et al. 2011).

The highstand systems tract (HST) above the MFS rarely developed, or even failed to develop, because of erosion after deposition of the $\mathrm{J}_{2} s^{1}$ Member. The top of the Conchostraca shale was in direct contact with the bottom of the overlying Jiaxiangzhai Sandstone. Therefore, SQ1 generally consists of a fining-upward lowstand and transgressive systems tract (LST + TST). The basal sandstone is the well-known Guankou Sandstone, which has many conglomeratic lag deposits at its base. Trough cross-bedding, tabular cross-bedding, and parallel bedding successively dominated upward, and wave-ripple bedding was evident at the top of this unit, which indicates fluvialdeltaic channel facies.

\subsubsection{Sequence 2 (SQ2)}

\section{Description}

SQ2 comprises the $\mathrm{J}_{2} s^{2}$ Member (Table 1; Figs. 5, 6). SQ2 thickens progressively from northeast to southwest 


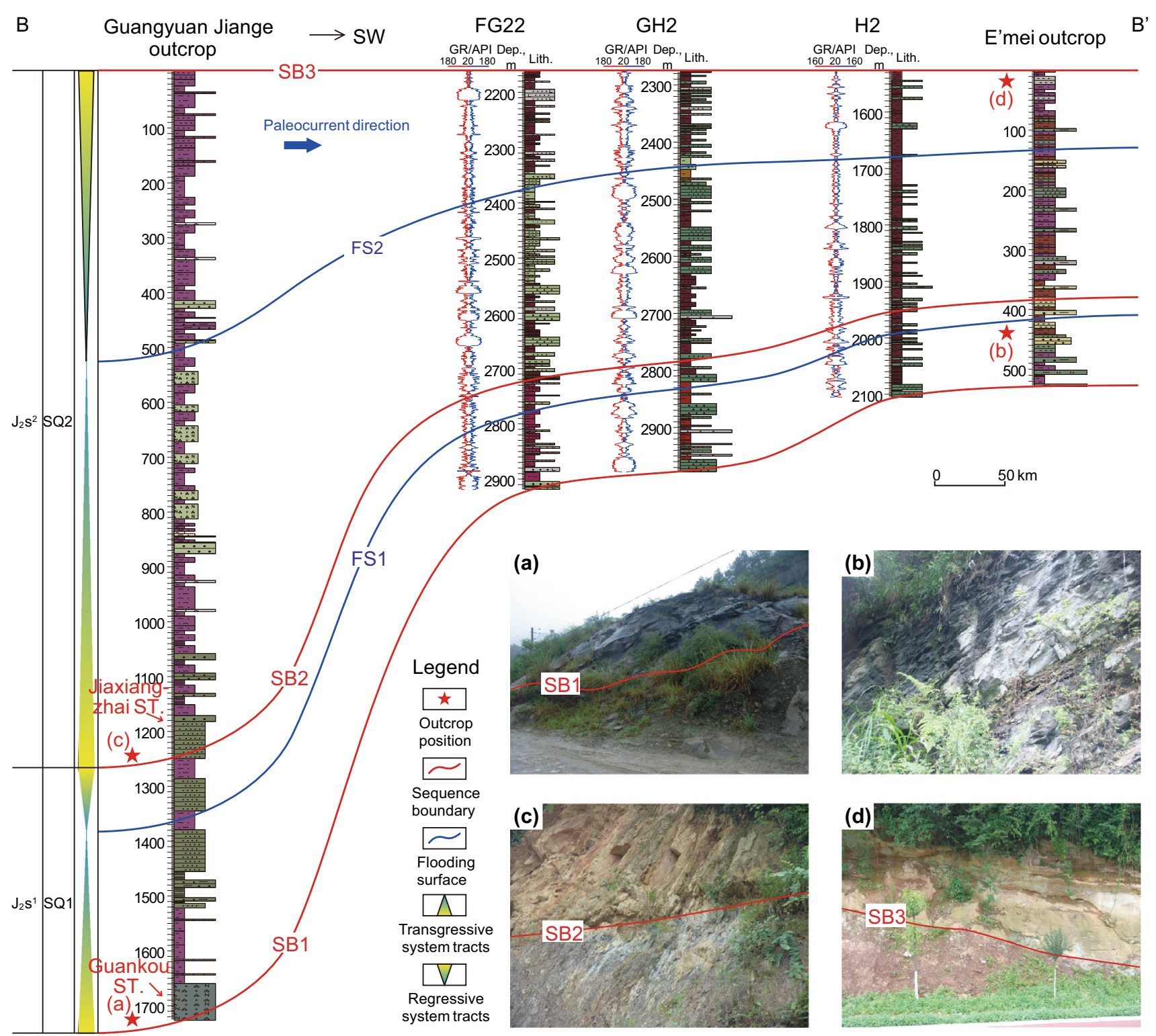

Fig. 5 Sequence-stratigraphic correlation of the Shaximiao Formation. The profile location is marked in Fig. 1. Two outcrops, at Guangyuan-Jiange (section P1 in Fig. 1) and E'mei (section P5 in Fig. 1), are represented in this profile. a Sequence boundary between

(Figs. 5, 6). Its thickness reaches at least $1300 \mathrm{~m}$, possibly more than $1500 \mathrm{~m}$, around Guangyuan-Jiange in the northeast, and declines to $400 \mathrm{~m}$ around E'mei-Ya'an in the southwest.

\section{Interpretation}

SQ2 was deposited in a similar tectonic setting and sedimentary environment to SQ1, and arid climatic conditions dominated the rejuvenated foreland basin during this period ( $\mathrm{Li}$ et al. 2009; Zhu et al. 2010). Vertically, SQ2 consists of coarsening upward sedimentary facies associations that transition from lacustrine beach bars to sandy braided-river deposits in the study area. This coarsening the Qianfoya Formation and the Shaximiao Formation. b Maximum flooding surface of the Shaximiao Formation. c Sequence boundary between the $\mathrm{J}_{2} s^{1}$ and $\mathrm{J}_{2} s^{2}$ members. $d$ Sequence boundary between the Shaximiao Formation and the Suining Formation

upward trend of facies associations within SQ2 is demonstrated further near De Yang; the internal SQ2 transition found east of the vertical section described above, progresses upward from deltaic facies to meandering-river deposits and then to braided-river facies. Additional evidence from the center of the basin reveals upward change from predominantly lacustrine to predominantly fluvial facies. Horizontally, this sedimentary system consists of fluvial overbank, deltaic, and lacustrine facies from the basin margin to its center.

In the study area, the LMVs developed mainly during the early stage of the LSTs and/or TSTs, the late stage of 


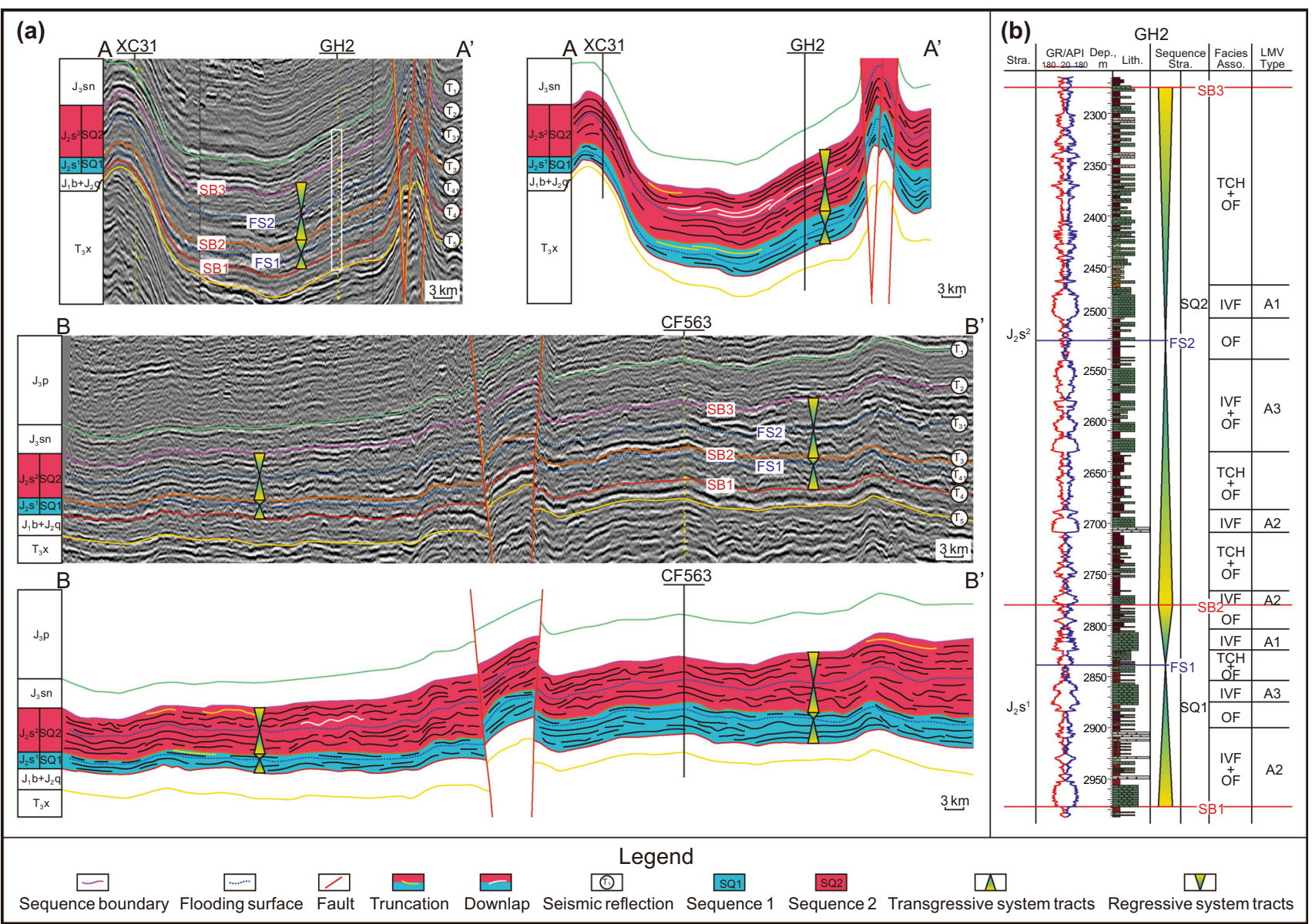

Fig. 6 Sequence-stratigraphic framework of the Shaximiao Formation in the middle part of the western Sichuan depression. a Cross section $\mathrm{AA}^{\prime}$ is oriented vertically to the LMTB marked in Fig. 1, with two calibrated wells; cross section $\mathrm{BB}^{\prime}$ is oriented vertically to

the HSTs and/or FSSTs, and the transitional period from FSST to LST. During these periods, the base level was consistently low because of the arid climatic conditions, and the sediment supply rate was greater than the basement subsidence rate (Zhu 2009; Li 2011; Qian et al. 2012); these conditions led to the formation of various scales of LMVs.

\subsection{Sedimentary characteristics of the LMVs}

Based on sequence-stratigraphic analysis of the Shaximiao Formation, we analyzed the lithofacies and sedimentary facies of individual valleys. A simple subdivision into gravel, sand, and fine-grained lithofacies is a useful initial step for description and classification (Miall 1985, 1996). In this study, nine dominant lithofacies, Gh, Gw, St, Sh, Sp, $\mathrm{Sw}, \mathrm{Sm}, \mathrm{Fl}$, and Fm, were considered in accordance with Miall's classification of fluvial lithofacies (Table 2). Gh indicates clast-supported gravel lithofacies with horizontal beddings and normal grading (Fig. 7a-b). Gw indicates
MDMTZ marked in Fig. 1, with one calibrated well. The target horizons were interpreted for both $\mathrm{AA}^{\prime}$ and $\mathrm{BB}^{\prime}$. b Sequencestratigraphic analysis of well $\mathrm{GH} 2$ in section $\mathrm{AA}^{\prime}$; see Table 3 for facies abbreviations

well-sorted and well-rounded gravel lithofacies. St, Sh, Sp, $\mathrm{Sw}$ and $\mathrm{Sm}$ indicate lithofacies of fine- to coarse-grained sandstones that are trough cross-bedded, horizontally laminated, planar cross-bedded, wavy bedded, and structureless (massive), respectively (Fig. 7a-f). Fm and Fl indicate lithofacies of mudstone or siltstone that are smallripple-laminated and structureless, respectively (Fig. 7g-i).

In previous studies, described infilled sequences and internal sedimentary facies of incised valleys have differed because of their different locations ( $\mathrm{Li}$ and Zhang 1996; Ferguson and Davis Jr. 2003; Rossetti and Santos Jr. 2004; Lin et al. 2005a, b; Breda et al. 2007; Yang et al. 2010; Ielpi 2012; Eoff 2014). However, certain interpretations have been agreed upon. First, channel, overbank, estuarine, and deltaic facies associations are the main facies associations represented in the infill deposits (Sakai et al. 2006; Wilson et al. 2007; Abrahim et al. 2008). Secondly, finingupward trends dominate in infill sedimentary sequences, such as in transitions from lower fluvial facies to upper deltaic facies. Based on these previous studies, we 
Table 2 Classification scheme of primary lithofacies within the LMVs of the Shaximiao Formation (Modified from Miall 1996)

\begin{tabular}{llll}
\hline $\begin{array}{l}\text { Facies } \\
\text { code }\end{array}$ & Facies & Sedimentary structures & Interpretation \\
\hline Gh & $\begin{array}{l}\text { Clast-supported, crudely bedded } \\
\text { gravel } \\
\text { Clast-supported, fine gravel }\end{array}$ & Horizontal bedding, normal grading & Lag/sieve deposits \\
Gw & Well sorted and well rounded & \\
St & Sand, fine to coarse & Solitary or grouped trough cross-beds & $\begin{array}{c}\text { Point-bar deposits with medium- to high-flow } \\
\text { regimes }\end{array}$ \\
Sh & Sand, fine to coarse & Horizontal lamination parting or streaming & $\begin{array}{c}\text { lineation } \\
\text { Sp }\end{array}$ \\
Sw & Sand, fine to coarse & Solitary or grouped planar cross-beds & Natural levees with lower-flow regimes \\
Sm & Sand, fine to coarse & Solitary or grouped wavy beddings & Scour fills, incised valley back-fills \\
& pebbly & Massive or faint lamination & Overbank/abandoned channel deposits \\
Fl & Fine grained, sand, silt, mud & Fine lamination, very small ripple & Floodplain (non-channelized) \\
& Fine grained, mud, silt & Massive &
\end{tabular}

classified three types of sedimentary facies associations (Table 3), incised valley-fill (IVF), tributary-channel (TCH), and overbank (OF) facies associations, by integrating facies markers recognized in outcrops, cores, seismic profiles, and well logs. IVF was subdivided into abandoned channel $(\mathrm{CH})$ and point bar $(\mathrm{PB})$, and $\mathrm{OF}$ was subdivided into alluvial flat (AF) and floodplain (FP). Among these facies associations, IVF is most dominant in the LMVs.

\subsubsection{Incised valley-fill}

In a narrow sense, channels are perennial and correspond to the lower part of fluvial systems that are constantly submerged underwater. In this study, the channel is a broad concept and includes the major channel as well as the marginal point-bar infills.

\subsubsection{Abandoned channel}

\section{Description}

Channel facies commonly develop at the base of depositional sequences in individual valleys, and fine upward into PB facies associations or the base of the next depositional sequence. For example, in the cores from well WJ2 in the Chengdu depression (Fig. 8), five channel depositional cycles are subdivided upward. These five hierarchies of channels were successively stacked vertically and became thinner upward with less complete cycles. Above the erosion surface at $3316.8 \mathrm{~m}$, conglomerate units could be subdivided into two belts, the lower of which consists of fine, highly mature conglomerate, whereas the upper belt of quartz conglomerate exhibits low maturity.

In terms of lithology, sandy $\mathrm{CHs}$ (SCHs) are characterized by conglomeratic lag deposits, conglomeratic sandstone, and medium- to coarse-grained sandstone at the base (Figs. 7a-f, 8); the cumulative grain-size distribution curves of such deposits present a three-segment pattern (Fig. 10d) with relatively small amounts of suspended sediments. Dominant sedimentary structures are basal boundary surfaces and boulder clay (Figs. 7a-b, 10).

\section{Interpretation}

Channel facies comprise one of the main facies associations in individual valleys. The $\mathrm{CH}$ classification can be subdivided into SCH and muddy channels (MCH) based on the last type of infill deposited. SCHs are more common than MCHs because MCHs are less likely to be preserved after millions of years.

Channels may migrate laterally and stack vertically because of autocyclic processes, as in the case of the five channel cycles in well WX 2, which were attributed to gradually decreasing accommodation and frequent major channel diversions (Fig. 8). The divisions above the erosion surface at 3316.8 mare presumed to have occurred for the following two reasons. (1) The previously accumulated sediments had high structural maturity because of secondary transportation from distant provenance. Overlying quartz conglomerates scoured the previously deposited pebbles because of valley progradation or flooding episodes. (2) Lower and upper conglomerates were deposited by the same flooding episodes and separated by differential settlement effects.

\subsubsection{Point bar}

\section{Description}

PBs formed through lateral migration and accretion and subsequently developed on the convex sides of the fluvial system; these deposits overlie channel facies and pass 

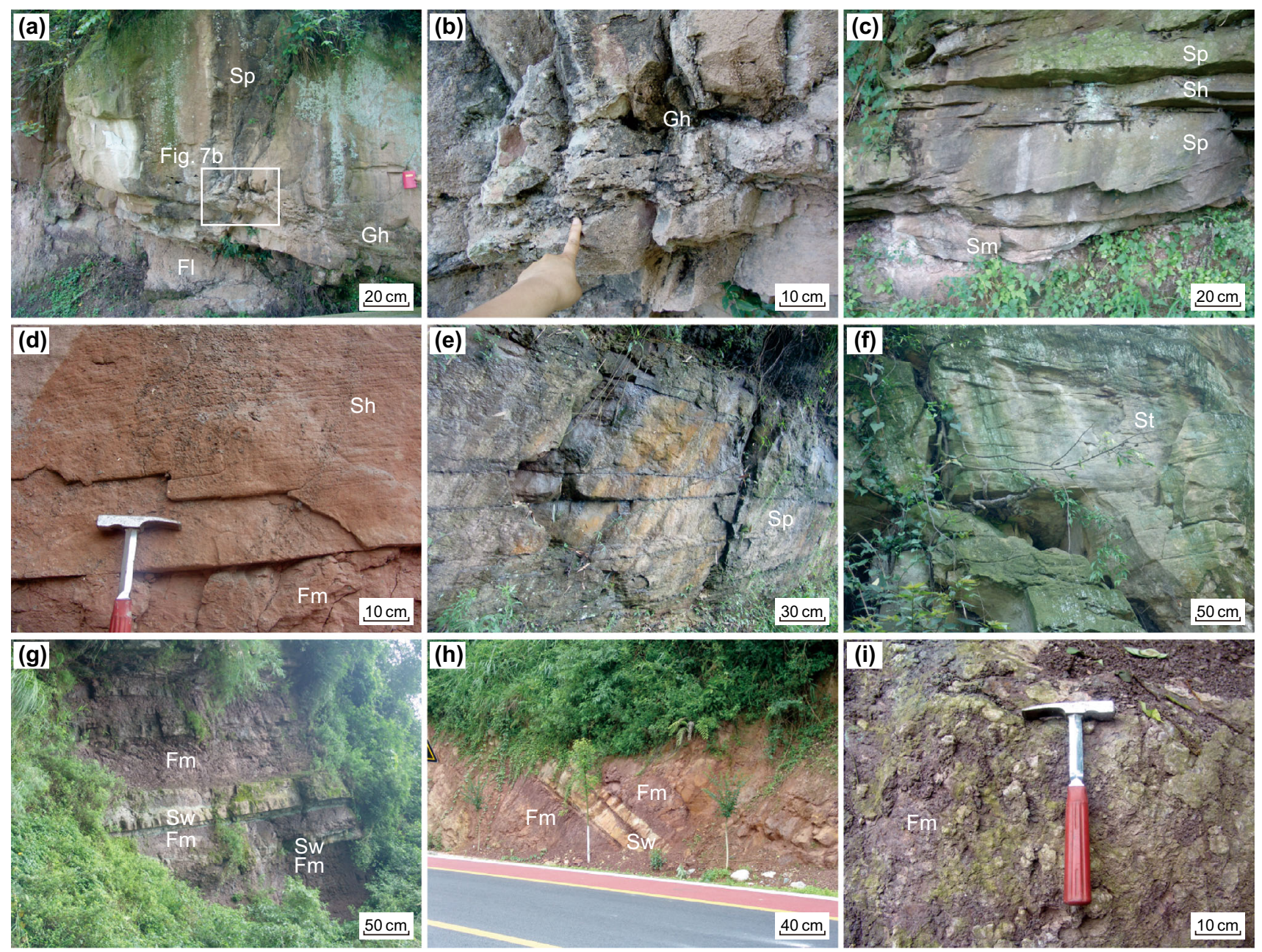

Fig. 7 Representative outcrop photographs showing the lithofacies of the Shaximiao Formation. All outcrop positions are labeled in Fig. 1. a Channel $(\mathrm{CH})$ facies with a basal bounding surface, above which is a thick sandy $\mathrm{CH}$ unit (Gh, Sp), and below which is brown floodplain mudstone to siltstone (Fl). Section P7 in Fig. 1. Magnification of the erosional belt indicated in the rectangular area shows $\mathbf{b}$ lag deposits (Gh) of sandy $\mathrm{CH}$, with conglomerate and stratified pebbly sandstone. Section P7 in Fig. 1. c Cross-bedded unit that consists of CH and LA elements (Sh, Sp). Section P6 in Fig. 1. d Point-bar facies with largescale parallel bedding (Sh, Fm). Section P2 in Fig. 1. e Point-bar

upward into the FP facies or the base of the river's next sedimentary sequence (Fig. 8). PB facies are lithologically finer than $\mathrm{SCH}$ facies; furthermore, $\mathrm{PB}$ facies are characterized by medium- to fine-grained sandstone, with cumulative grain-size distribution curves that sort well into two section types (Fig. 10d). Moreover, large-scale inclined bedding with mica pieces is more prevalent in PBs than in SCHs (Fig. 10c) because of their different flowregime conditions. Other bedding types with a highstrength flow, such as large-scale trough cross-bedding, wedge bedding, and parallel bedding, are also commonly observed in PB facies (Figs. 7c-f, 10). facies with large-scale wedge cross-bedding ( $\mathrm{Sp}$ ), representing a highstrength flow. Section P5 in Fig. 1. f Point-bar facies with trough cross-bedding (St). Section P7 in Fig. 1. g Alluvial-flat facies, brown to red-brown mudstone interbedded with siltstone and fine-grained sandstone ( $\mathrm{Sw}, \mathrm{Fm})$. Section P5 in Fig. 1. h Alluvial-flat facies, brown mudstone interbedded with siltstone and fine-grained sandstone (Sw, Fm). Section P3 in Fig. 1. i Alluvial-flat facies (Fm); note the iron concretions, which indicate the warm and arid climatic conditions. Section P4 in Fig. 1

In outcrop, PB facies are typically characterized by lateral accretion units. For example, representative Shaximiao Formation fluvial facies associations exposed in the Guangyuan-Jiange profile (Fig. 9a; see section P1 in Fig. 1) are divided into three-fourth-order channel architectural elements (Fig. 9b). PBs include third-order architectural elements (such as lateral accretions, downstream accretions, and sandy bedforms) and are recognized in the 1-IVF and 3-IVF units (Fig. 9b) based on evident internal lateral accretion bedding. After analyzing the internal configuration of the 1-IVF unit, we have recognized three fluvial systems from the base upward; sedimentary structures are dominated by large-scale planar and cross- 
Table 3 Classification and interpretation of sedimentary facies in LMVs in the Shaximiao Formation

\begin{tabular}{|c|c|c|c|}
\hline Association & Facies & Facies description & Process interpretation \\
\hline \multirow[t]{2}{*}{$\begin{array}{l}\text { Incised } \\
\text { valley-fill } \\
\text { (IVF) }\end{array}$} & $\begin{array}{l}\text { Abandoned } \\
\text { channel } \\
(\mathrm{CH})\end{array}$ & $\begin{array}{l}\text { Includes sandy } \mathrm{CH}(\mathrm{SCH}) \text { and muddy } \mathrm{CH}(\mathrm{MCH}) \text {, mainly } \\
\text { basal conglomerate, gravelly sandstone, coarse- to } \\
\text { medium-grained sandstone; basal bounding surface, } \\
\text { boulder-clay deposits; at the bottom of the depositional } \\
\text { sequence with a fining-upward trend }\end{array}$ & $\begin{array}{l}\text { Channel-bottom lag deposition, migration of } \\
\text { channelized bedforms; vertical accretion and lateral } \\
\text { migration; high-strength flow }\end{array}$ \\
\hline & $\begin{array}{l}\text { Point bar } \\
\text { (PB) }\end{array}$ & $\begin{array}{l}\text { Medium- to fine-grained sandstone; large-scale trough } \\
\text { cross-bedding, cross-bedding, parallel bedding; overlies } \\
\text { Ch, with typical lateral accretion bedding }\end{array}$ & $\begin{array}{l}\text { Lateral accretion and lateral migration; medium- } \\
\text { strength flow }\end{array}$ \\
\hline \multicolumn{2}{|c|}{ Tributary channel $(\mathrm{TCH})$} & $\begin{array}{l}\text { Developed together with the incised valley, but smaller in } \\
\text { size relative to the incised valley; fine- to medium-grained } \\
\text { sandstone; basal bounding surface, muddy clasts; at the } \\
\text { bottom of the depositional sequence with a fining-upward } \\
\text { trend }\end{array}$ & $\begin{array}{l}\text { Channel-bottom lag deposition; vertical accretion } \\
\text { and lateral migration; high-strength flow }\end{array}$ \\
\hline \multirow{2}{*}{$\begin{array}{l}\text { Overbank } \\
\text { facies } \\
(\mathrm{OF})\end{array}$} & $\begin{array}{l}\text { Alluvial flat } \\
\text { (AF) }\end{array}$ & $\begin{array}{l}\text { Gray, fine-grained sandstone, siltstone, pelitic siltstone; } \\
\text { current-ripple lamination, cross-bedding; overlies IVF, } \\
\text { and is coupled with FP deposits }\end{array}$ & Medium- to low-strength flow \\
\hline & $\begin{array}{l}\text { Floodplain } \\
\text { (FP) }\end{array}$ & $\begin{array}{l}\text { Celadon to brown mudstone, silty mudstone; horizontal } \\
\text { bedding }\end{array}$ & $\begin{array}{l}\text { Medium- to low-strength flow, rarely flood-fan } \\
\text { deposition with turbidity currents }\end{array}$ \\
\hline
\end{tabular}

bedding (Fig. 9c), which indicate that unloading in the fluvial system was dominated by traction currents. The multiple stages of PB facies (i.e., LA or DA elements) are observed based on internal evidence. At region d in Fig. 9, one PB unit with recognizable lateral accretion bedding was truncated early by channel-fill facies (Fig. 9d); at region e, PBs with recognizable lateral accretion bedding were truncated by an overlying channel (Fig. 9e).

\section{Interpretation}

Similar to SCHs, the PB facies association is one of the main types of sandstone body in individual valleys. PBs can be differentiated from SCHs based on sorting and lateral accretion bedding (Fustic et al. 2012). DA macroforms, LA deposits, and sandy bedforms are the most common architectural elements in PB facies (Miall 1996). In general, $\mathrm{PB}$ sandstones are not recognizable in seismic profiles or well logs, whereas outcrop and core data are reliable for investigating these units.

The Guangyuan-Jiange profile (Fig. 9) is oriented NW$\mathrm{SE}$, which is perpendicular to the paleocurrent direction (P1 in Fig. 1); therefore, depositional units with lateral accretion can be interpreted as PBs. Additionally, the depositional evolution of the incised valleys can be interpreted as follows. During the development of the 1-IVF unit, valleys formed in early stages with relatively high accommodation. The main channel migrated northwestward, and the resulting lateral accretion units constitute the dominant sedimentary bodies in the most notable outcrop. During the development of the 2-IVF unit, SCH was deposited from its concave-up erosion surface upward because of the relatively low accommodation; the main channel migrated southwestward and truncated the fluvial systems of the 1-IVF unit. During the development of the 3-IVF unit, the major channels changed route again and migrated northwestward based on the internal northwestinclined lateral accretion bedding; these units can be interpreted as PBs. Therefore, as interpreted from the outcrop, there were multiple stages of channel crosscutting.

\subsubsection{Tributary channel}

\section{Description}

TCH deposits developed at the same time as coeval incised valleys, but their geometric parameters (width and depth) are much smaller than those of the corresponding incised valleys. TCH fills primarily consist of the Gw, Sh, Sp, Sw and Sm lithofacies (Fig. 7a-f). Planar cross-beds and several erosional structures, such as basal bounding surfaces, lag deposits and muddy clasts, were observed in the core.

2. Interpretation

Tributary channels and major channels within LMVs have similar sedimentary characteristics but can be distinguished based on the following aspects: major channels developed within long, wide, confined areas, which result in lowfrequency lateral accretion but high-frequency vertical accretion. In contrast, tributary channels are distributed horizontally across much broader, flat regions, which results in high-frequency lateral migration and low-frequency vertical accretion. 




Fig. 8 Channel facies analysis of core data from well WJ2. The vertical core section was analyzed based on core description, and five $\mathrm{SCH}$ depositional cycles were subdivided; see text for detailed descriptions. Note the two erosional surfaces at which the contrast in lithology is apparent. a-f Representative images for the vertical section; the intervals shown in (a)-(c) developed within the same channel-fill, and the intervals (d)-(e) developed in another shared channel-fill. a Point-bar facies with parallel-bedded sandstone,

\subsubsection{Overbank facies}

\section{Description}

OF facies are found overlying channel facies in complete sedimentary sequences and can be subdivided into AF and FP deposits based on sedimentary environment and characteristics (Fig. 10). In the study area, OF deposits are characterized by brown to red-brown mudstone interbedded with siltstone and fine-grained sandstone with rare sedimentary structures (Fig. 7g-i); these characteristics
3,311.2 $\mathrm{m}$ in depth. b Sandy channel facies with fining-upward cycles, $3,315.5 \mathrm{~m}$ in depth. c Erosional belt conglomerate unit, 3,315.80 $\mathrm{m}$ in depth. d Point-bar facies with cross-bedded sandstone, 3,317 $\mathrm{m}$ in depth. e Sandy channel facies with fining-upward cycles, 3,317.7 $\mathrm{m}$ in depth. f Conglomeratic lag deposits with low maturity, $3,318 \mathrm{~m}$ in depth. For scale, the diameter of the coin is approximately $3.5 \mathrm{~cm}$

indicate overflow deposition in a shallow-water environment.

AF deposits are lithologically dominated by thin- to medium-bedded siltstone and fine-grained sandstone with rare sedimentary structures. FP facies are found at the very top of fluvial sedimentary sequences, but are scarcely preserved in a single valley influenced by low accommodation and the resulting rechanneling and cross-cutting. FP facies are lithologically dominated by fine-grained sediments, such as shale and argillaceous siltstone rich in 

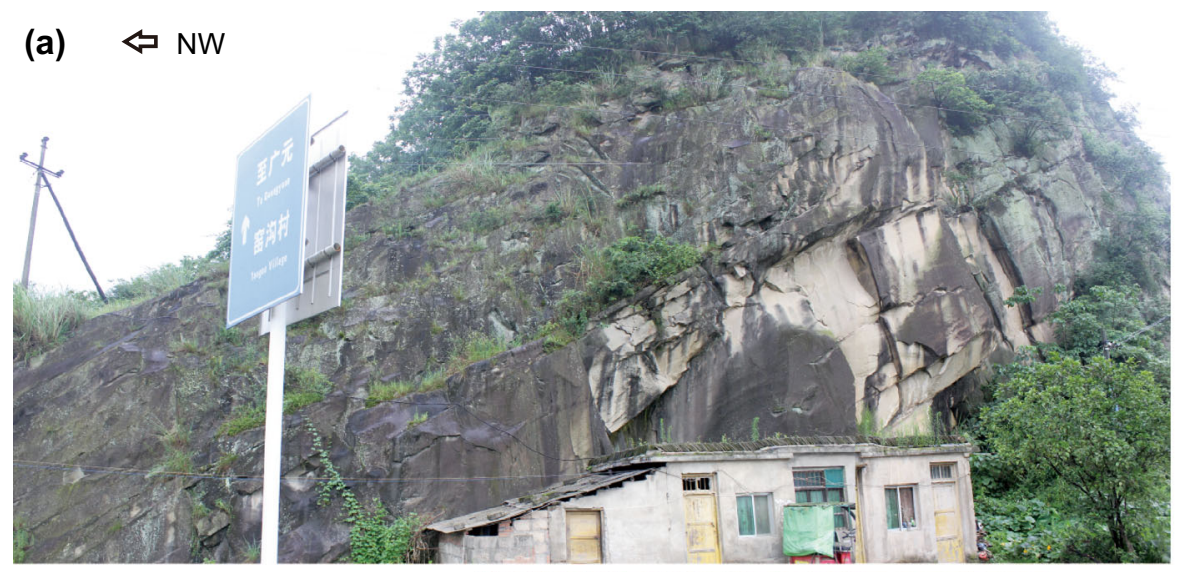

(b)
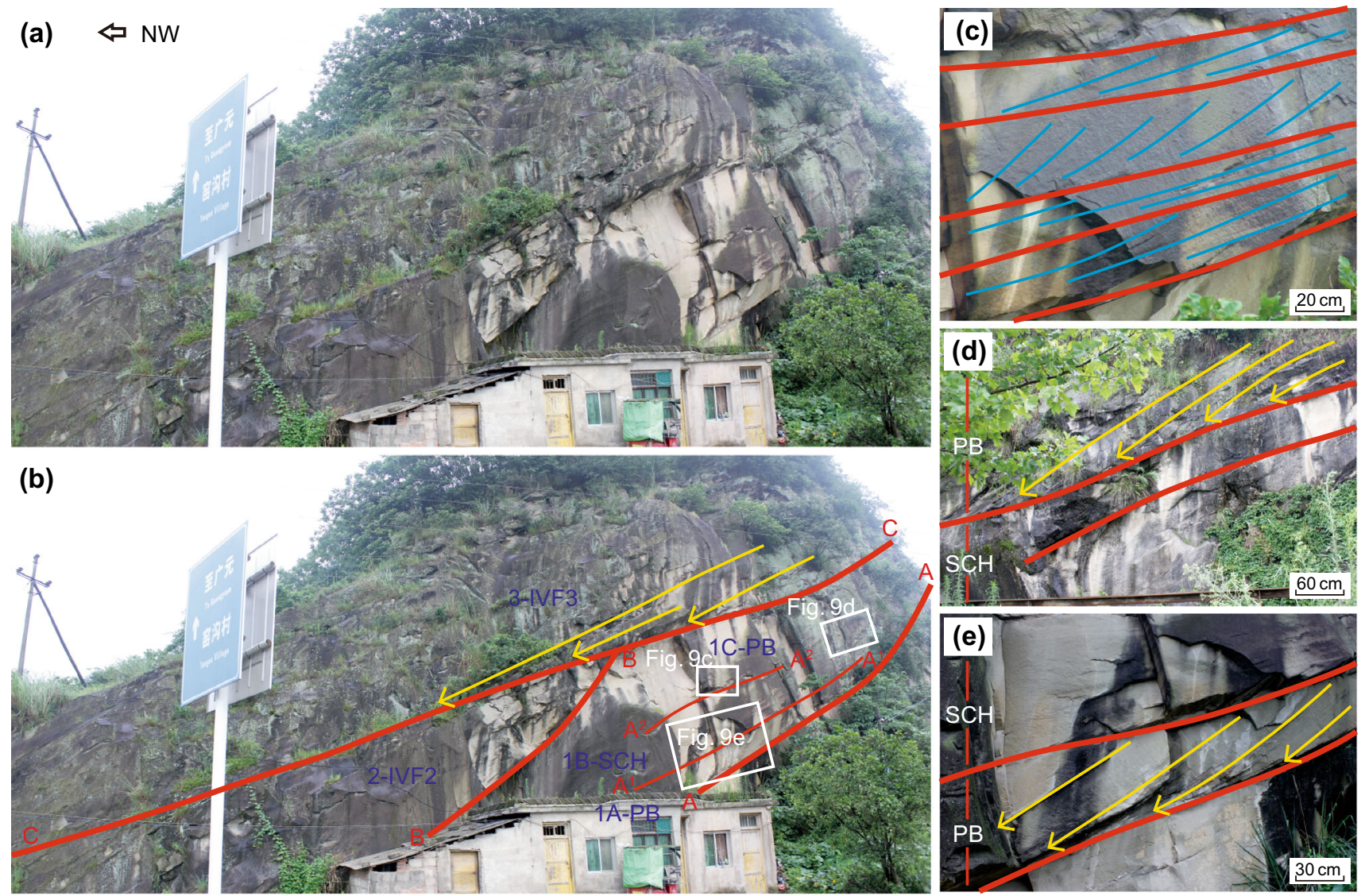

Fig. 9 Analysis of outcrop architectural elements and depositional facies of the Shaximiao Formation LMVs. a Representative photographs facing southwest to show the cross-cutting relationships of different stages of channel-fill. See the location labeled in Fig. 1, section P1. b Architectural element analysis and interpretation of an outcrop profile. Note three-fourth-order bounding surfaces outlined by A to $\mathrm{C}$, two-third-order bounding surfaces recognized within the 1-IVF unit, three identified channel-fills, and 1-IVF subdivided into three sedimentary units. Three rectangular areas showing detailed

organic matter. Sedimentary structures in FP facies are characterized by parallel and wavy laminations associated with low-strength flow.

\section{Interpretation}

The AF is the basal flat region of a valley. Water on the AF will evaporate or penetrate into the subsurface during the normal season in this region, but the AF will be submerged when flooding occurs.

The FP represents relatively low regions between channels in valleys, and its sedimentation is characterized by fine-grained deposition. Water may remain on the FP even after a flood has receded. The processes, rates, and patterns of FP reworking in the reaches in the LMVs have been defined, and these findings contribute toward understanding the mechanisms by which sediments are deposited, modified, and preserved in rivers (Keen-Zebert et al. 2013). elements are outlined and magnified in $(\mathbf{c}-\mathbf{e}) . \mathbf{c}$ Point-bar facies with large-scale tabular cross-bedding. d Sandy channel with concave-up erosional surface cut by overlying point-bar lateral accretion units. e Typical lateral accretion units showing point-bar facies cut by overlying sandy channel. See text for detailed descriptions of architecture elements. The red lines are labeled as 6-ordered sequence boundaries, the yellow lines are labeled as lateral accretions, and the blue lines are labeled as cross beddings

\section{Discussion}

Two primary issues remain to be investigated and discussed. (1) Further investigations should be conducted regarding the stacking patterns of LMVs in different stages and the sequence architectures associated with base-level fluctuation. (2) Whether the LMVs evaluated in this study developed widely in the foreland basin during tectonically stable periods, as well as which model should be used to interpret the evolutionary processes of the valleys, remain to be determined.

Fluvial incision may be driven by one or more of the following: autogenic forcing, such as fluvial vertical accretion, and/or allogenic forcing, such as tectonism, climatic change, variation in sediment supply, and increase in discharge. In this study, the subsidence rate in the study area during deposition of the $\mathrm{J}_{2} s$ Formation was relatively 

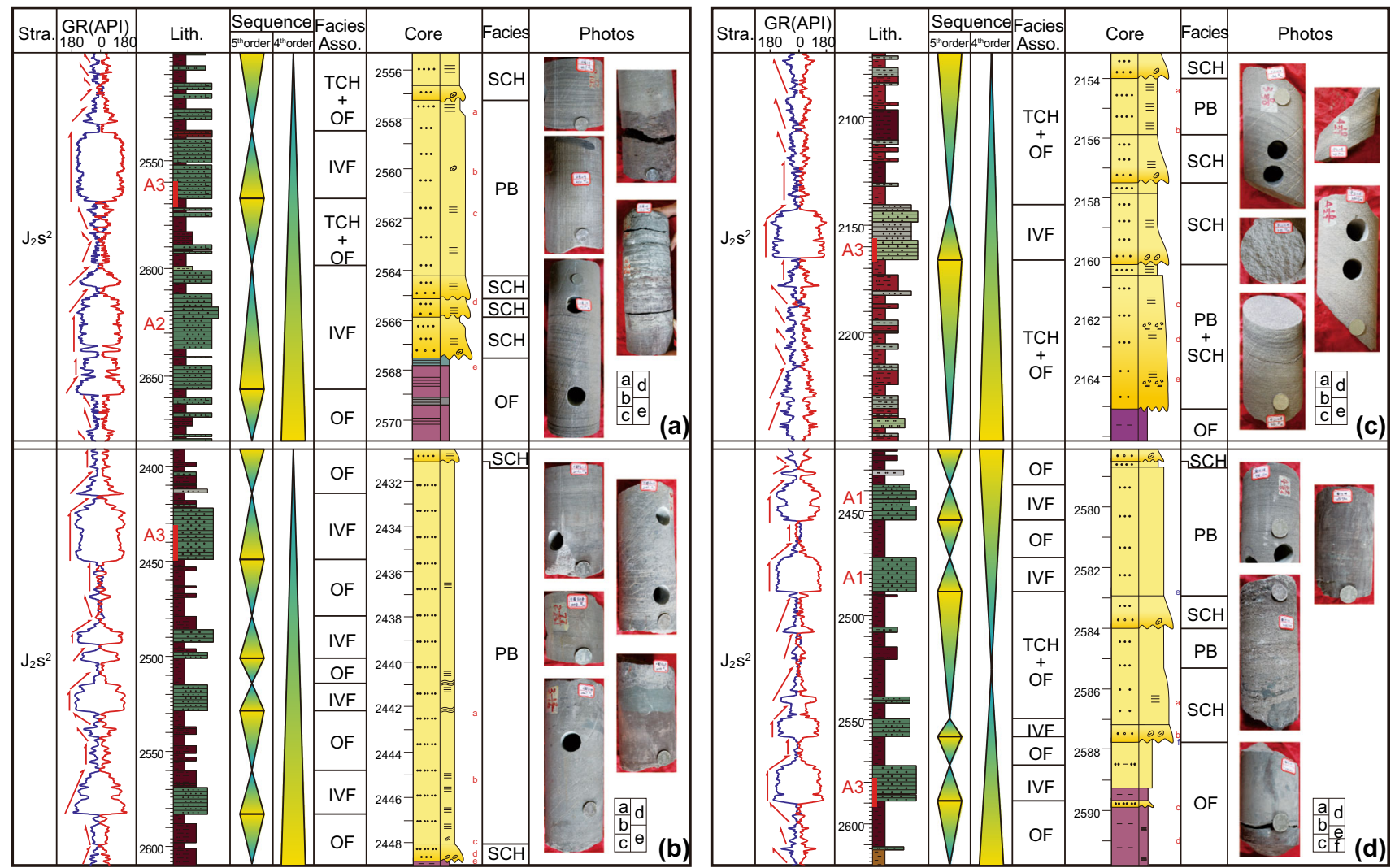

Legend

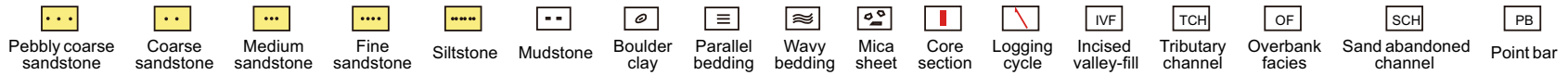

Fig. 10 Single-well sections for interpretation of the facies within the LMVs based on core and grading analysis. Core facies interpretations for four wells from facies-association scale to facies scale; well positions are marked in Fig. 1; $\mathbf{a}=\mathrm{WX} 2 ; \mathbf{b}=\mathrm{CD} 620 ; \mathbf{c}=\mathrm{ZJ} 10$; and $\mathbf{d}=\mathrm{DSh} 2$. Three types of LMV, A1, A2, and A3, are labeled in the vertical section. Note that the core photographs are labeled $\mathbf{a}, \mathbf{b}, \mathbf{c}$, etc., to show different sedimentary structures in the core. a Three facies associations were recognized based on electrofacies analysis; note that four stages of channel-fill were identified in the core section. Photographs a, b, and c show large-scale parallel bedding and cross-bedding, interpreted as point-bar facies; d shows a basal boundary surface, interpreted as sandy channel facies; e shows variegated mudstone, interpreted as floodplain facies. b Three facies associations were recognized based on electrofacies analysis. Note that two stages of channel-fill were identified in the core section. Photographs $\mathrm{a}$ and $\mathrm{b}$ show parallel bedding and wavy laminations; $\mathrm{c}$ and $\mathrm{d}$

consistent at approximately $90 \mathrm{~m} / \mathrm{Ma}$ (Zhu 2009; Cheng 2014), and the sediment supply rate can be regarded as a constant (Li et al. 2009; Zhu 2009; An 2011). Therefore, variations in the preserved sedimentary sequence can be attributed to base-level changes and/or autogenic factors.

\subsection{Base-level control on the sequence architecture}

The base level is analogous to a potential energy surface that describes the directions in which sedimentation, show boulder clays; and e shows a basal bounding surface, interpreted as sandy channel facies. c Three facies associations were recognized based on electrofacies analysis. Note that four stages of channel-fill were identified in the core section. Photographs a, b, c, d, and e show large-scale parallel bedding and cross-bedding, interpreted as pointbar facies. d Three facies associations were recognized based on electrofacies analysis. Note that three stages of channel-fill were identified in the core section. Photographs a and b show large-scale parallel bedding and cross-bedding with boulder clay at the bottom, interpreted as sandy channel facies; c shows a burrow structure; and d shows brown mudstone, interpreted as floodplain facies; e and $f$ are cumulative grain-size distribution curves, e shows a bi-segment pattern, interpreted as point-bar facies, and f shows a three-segment pattern, interpreted as sandy channel facies

sediment bypass, and erosion in a stratigraphic system are likely to occur (Shanley and McCabe 1994). Tectonic uplift and climatic changes can drive the base level; however, their influence varies from upstream to downstream. The mid- to downstream segments of rivers are primarily controlled by lake- or sea-level (analogous to the base level) changes (Hampson et al. 2012; Alqahtani et al. 2015), whereas the upstream segments of rivers may be more directly controlled by tectonism (Shanley and McCabe 1994; Mattheus et al. 2007; González-Bonorino et al. 2010; Alqahtani et al. 2015). 
The seismically imaged valleys correspond to mid- to downstream parts of the $\mathrm{J}_{2}$ s incised valleys (Fig. 1), which were closer to the perennial lake (Fig. 2a; An 2011; Li et al. 2012). Therefore, relative lake-level fluctuations could have exerted significant control on the form and evolution of the incised valleys.

During deposition of the studied strata, the climate was becoming more arid over time (Cao 2007; Wang et al. 2008; Qian et al. 2012), which resulted in evaporation and lake-level fall. Three types of LMVs (Fig. 11), A1, A2, and A3, developed along with base-level (lake-level) changes, among which the base level for A3 LMV was likely the lowest. This division is based on sequence stratigraphy and the LMV sedimentary characteristics of the Shaximiao Formation in the western Sichuan depression, including sequence boundaries and the internal sequence-stratigraphic characteristics of systems tracts.

These three types of LMV, A1, A2, and A3, developed in different stages of sequence infilling and show inheritance from each other in time and space (Table 4, Fig. 11). Periodic base-level (lake-level) fluctuations controlled the progradation and retrogradation of the valleys (Shanley and McCabe 1994; Olsen 1995). The widths and depths of the incised valleys were controlled mainly by the rate and magnitude of local base-level fall and delayed accommodation (Alqahtani et al. 2015).
Fig. 12 Seismic facies and well-correlation framework showing the sedimentary facies and geometry of IVF in the $\mathrm{J}_{2} s_{1}^{3}$ sub-member (A1), $\mathrm{J}_{2} s_{2}^{1}$ sub-member (A2), and $\mathrm{J}_{2} s_{2}^{2}$ sub-member (A3). All of the wells crossed are formation top flattened. See the text for details

These three types of LMV with varying sequence architectures are genetically inherited vertically. LMVs increase in horizontal sinuosity from type A1 to type A3 (Fig. 12), but maximum width and depth are achieved during periods of type A3. The overall vertical sedimentary section is lithologically characterized by fining-upward cycles. This phenomenon strongly indicates the regularity of valley evolution in terms of overall morphology and vertical succession with base-level fluctuations in a foreland basin setting during tectonically stable periods.

\subsection{Sedimentary evolution model}

In the present paper, LMV sedimentary evolution models are divided into three stages based on analysis of the sequence architecture and sedimentary characteristics of LMVs in the Shaximiao Formation. We have also considered the influence of fifth-order base-level cycles on LMV development. Three stages are noted as follows (Fig. 13): an incision-dominated valley evolution pattern in the early stage; an inherited incision-dominated valley evolution


Legend

$\checkmark$ TypeA1 LMVs $ح$ TypeA2LMVs $ح$ TypeA3LMVs $\triangle$ Transgressive systems tract $\nabla$ Regressive systems tract

Conglomerate $\square$ Fine-coarse sandstone $\quad$ Mudstone Parallel cross bedding $\quad$ W Trough cross bedding $\mathrm{mm}$ Cross lamination

Fig. 11 Lake-level changes and sequence architectures of LMVs in the middle part of the western Sichuan depression. a $\mathrm{J}_{2} s_{1}^{3}$ (A1 in Fig. 12), $\mathrm{J}_{2} s_{2}^{1}$ (A2 in Fig. 13), and $\mathrm{J}_{2} s_{2}^{2}$ (A3 in Fig. 14) LMVs are labeled and related to lake-level changes. The curve data are from Cao (2007) and Qian et al. (2012). b Typical vertical section showing different sedimentary infill cycles corresponding to the respective sequence architectures of LMVs. Full lithological meanings of the abbreviations are given in Table 2. See text for more detailed descriptions 

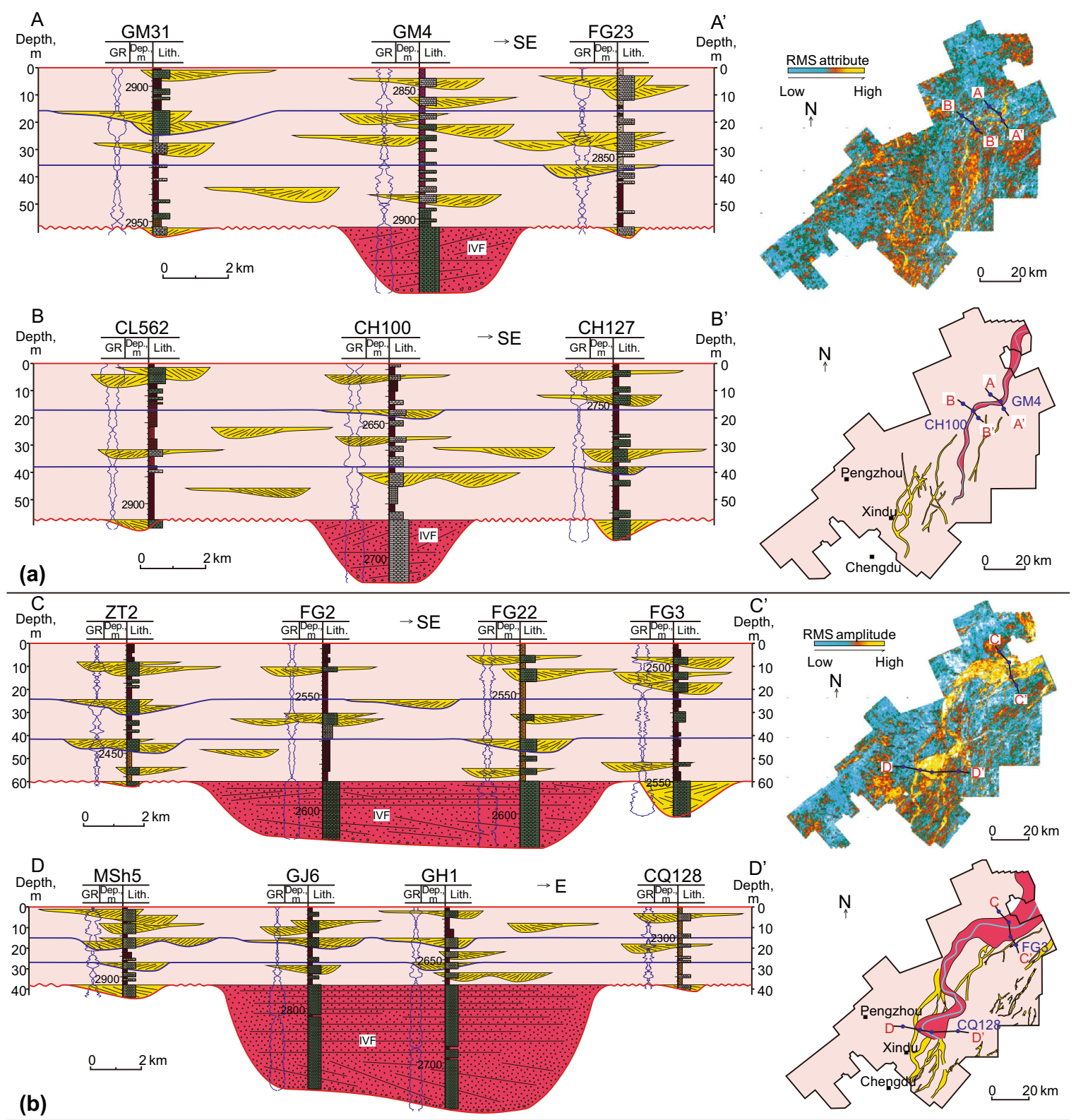

(b)

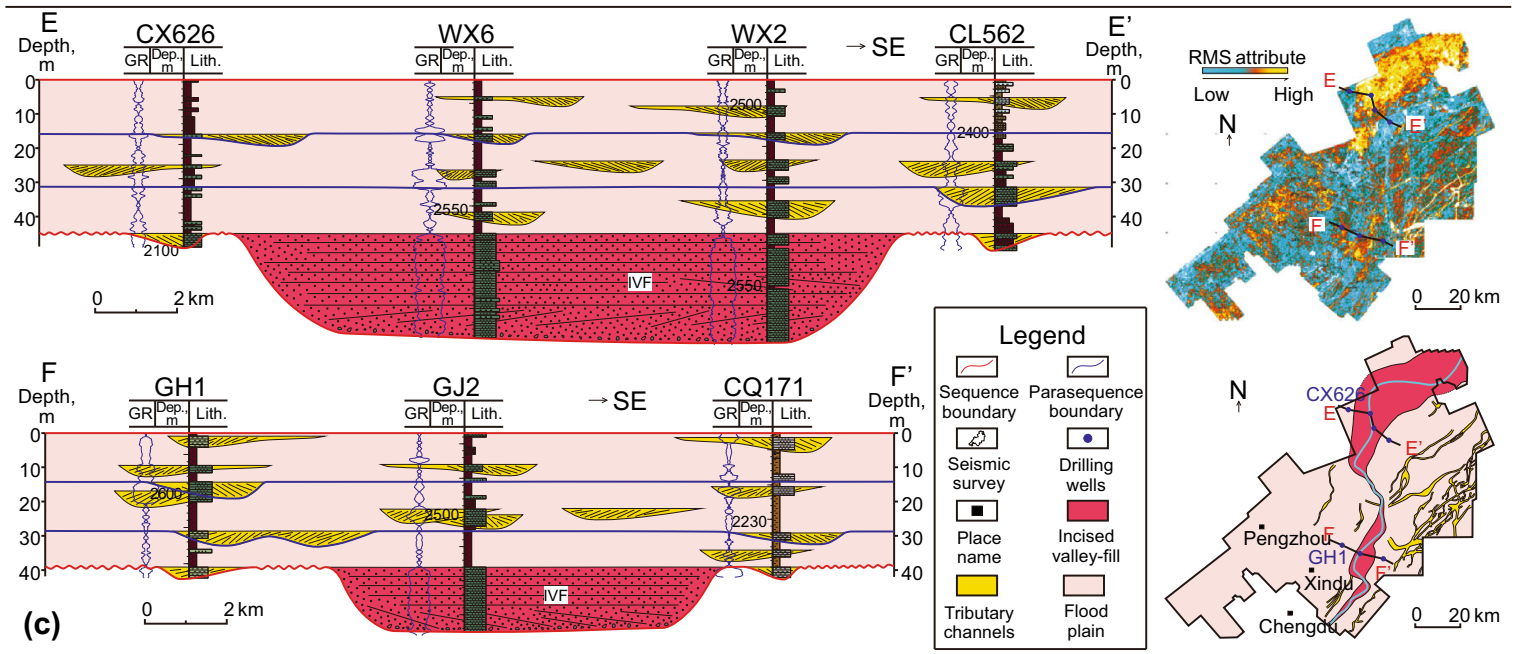




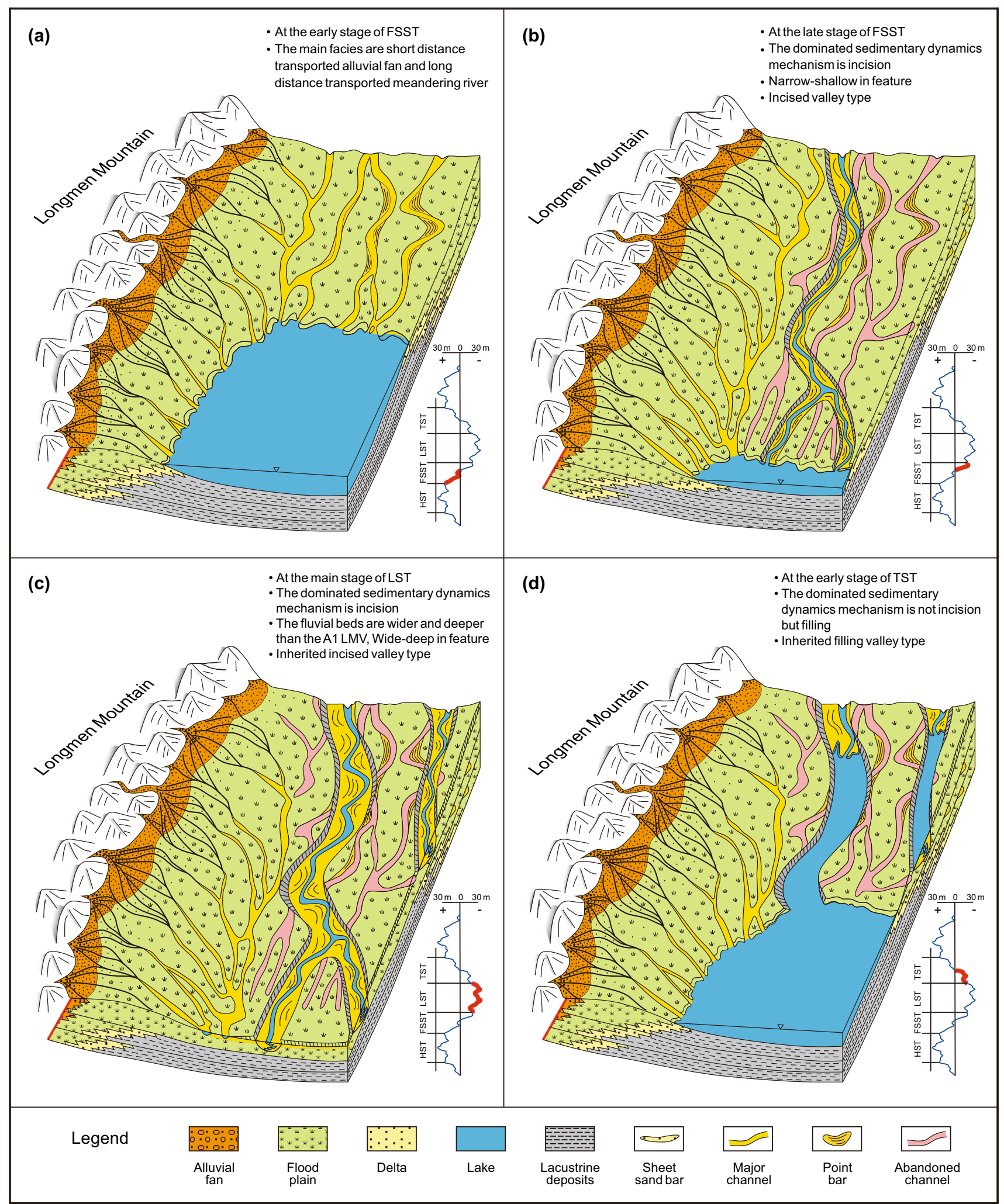

Fig. 13 Sequence-sedimentary infill evolution model of the Shaximiao Formation LMVs in the western Sichuan depression. LST lowstand systems tract; TST transgressive systems tract; HST highstand systems tract; FSST falling-stage systems tract. Influenced by fifth-order base-level changes, four LMVs evolutionary stages are summarized in (a) to (d), and among which (b) to (d) are the main phases during which the LMVs developed. b Incision-dominated early evolutionary stage. c Inherited incision-dominated middle evolutionary stage. d Filling-dominated late evolutionary stage 
Table 4 Classification of LMV types with base-level changes and sedimentary characteristics

\begin{tabular}{|c|c|c|c|c|c|c|c|}
\hline \multirow{2}{*}{$\begin{array}{l}\text { LMV } \\
\text { type }\end{array}$} & \multirow[t]{2}{*}{ Lithology } & \multirow[t]{2}{*}{ Depositional period } & \multirow[t]{2}{*}{ Geometry } & \multirow{2}{*}{$\begin{array}{l}\text { Typical sub- } \\
\text { members }\end{array}$} & \multicolumn{3}{|c|}{ Examples in this paper } \\
\hline & & & & & & $\begin{array}{l}\text { Width, } \\
\text { km }\end{array}$ & $\begin{array}{l}\text { Depth, } \\
\mathrm{m}\end{array}$ \\
\hline \multirow[t]{2}{*}{ A1 } & \multirow[t]{2}{*}{ St, Sp, and Sw } & \multirow{2}{*}{$\begin{array}{l}\text { Late stage of HST and/or } \\
\text { FSST }\end{array}$} & \multirow{2}{*}{$\begin{array}{l}\text { Narrow/ } \\
\text { shallow }\end{array}$} & \multirow[t]{2}{*}{$\mathrm{J}_{2} s_{1}^{3}$} & $\mathrm{AA}^{\prime}$ & 5.2 & 24.9 \\
\hline & & & & & $\mathrm{BB}^{\prime}$ & 4.1 & 23.1 \\
\hline \multirow[t]{2}{*}{ A2 } & \multirow{2}{*}{$\begin{array}{l}\mathrm{Gh}, \mathrm{Gw}, \mathrm{St}, \mathrm{Sh}, \mathrm{Sp}, \mathrm{Sw} \text {, and } \\
\mathrm{Sm}\end{array}$} & \multirow{2}{*}{$\begin{array}{l}\text { LST and/or early stage of } \\
\text { TST }\end{array}$} & \multirow[t]{2}{*}{ Wide/deep } & \multirow[t]{2}{*}{$\mathrm{J}_{2} s \stackrel{1}{2}$} & $\mathrm{AA}^{\prime}$ & 13.5 & 27.2 \\
\hline & & & & & $\mathrm{BB}^{\prime}$ & 16.3 & 55.5 \\
\hline \multirow[t]{2}{*}{ A3 } & \multirow[t]{2}{*}{ Gh, St, Sh, Sp, Sw, Fl, and Fm } & \multirow[t]{2}{*}{ Early stage of TST } & \multirow[t]{2}{*}{ Wide/deep } & \multirow[t]{2}{*}{$\mathrm{J}_{2} \mathrm{~S}_{2}^{2}$} & $\mathrm{AA}^{\prime}$ & 16.0 & 31.4 \\
\hline & & & & & $\mathrm{BB}^{\prime}$ & 8.7 & 18.9 \\
\hline
\end{tabular}

pattern in middle stage; and a filling-dominated valley evolution pattern in late stage.

\subsubsection{Incision-dominated early evolutionary stage}

The western Sichuan depression in the Middle Jurassic was characterized by widely developed fluvial systems in the early FSST (Fig. 13a), in which LMVs formed in the early incision-dominated stage because of the arid climate and continuously decreasing base level (Fig. 13b). The valleys in this early evolutionary stage were small in depth and width; therefore, the dominant mechanism of the sedimentary dynamics was incision, which is characteristic of type A1 valleys in terms of sequence architecture.

\subsubsection{Inherited incision-dominated middle evolutionary stage}

As the base level consistently decreased, valleys entered their peak development periods, i.e., the inherited incisiondominated middle evolutionary stage (Fig. 13c). In this stage, valleys inherited the sequence patterns of the earlier incised valleys, and their main mechanism of sedimentary dynamics was incision. However, relative to the previous stage, the valleys may have undergone more intense downcutting erosion and lateral migration to produce much deeper and wider morphology, which is characteristic of type A2 in terms of sequence architecture. The corresponding seismic facies are clearly marked by seismic events, and can also be distinguished on attribute maps. Therefore, this type of valley has great significance for gasfield exploration and exploitation.

\subsubsection{Filling-dominated late evolutionary stage}

With gradual rise in base level, valleys entered the fillingdominated late evolutionary stage (Fig. 13d) as they aged. Valleys in this stage may become infilled with sediments unloaded by rivers with weak ability to suspend and transport.

\section{Conclusions}

The western Sichuan depression was tectonically stable as a rejuvenated foreland basin when the Middle Jurassic Shaximiao Formation was deposited. The basement subsidence rate in this depression was lower than the sediment supply rate. Fluvial and lacustrine red clastic sediments developed under semiarid to arid climatic conditions. For the first time, ancient LMVs were discovered in this area and studied using sequence-stratigraphic analysis and seismic sedimentology methods. The results of this study show that the incised valleys were 5-17 km wide, 20-60 m deep, and traceable for $120 \mathrm{~km}$ along their axes. These characteristics make these valleys among the longest seismically imaged incised valleys in the world.

Three sequence boundaries and two flooding surfaces were recognized and correlated using an integrated approach with field survey data and borehole logs to enable subdivision of the Shaximiao Formation into two-thirdorder sequences and four systems tracts. Based on core descriptions, seismic facies analysis, and comprehensive application of the drilling data, we categorized three sedimentary facies associations: IVF, TCH, and OF. IVF is subdivided into $\mathrm{CH}$ and $\mathrm{PB}$, whereas $\mathrm{OF}$ is subdivided into AF and FP. IVF is the most dominant facies in the LMVs.

The role of tectonism gradually diminishes in the downstream direction, and periodic base-level changes control the form and evolution of the incised valleys. The LMV sedimentary evolution model was divided into three stages based on the influence of base-level changes: incision-dominated valley evolution in the early stage, inherited incision-dominated valley evolution in the middle stage, and filling-dominated valley evolution in late stage. The valleys developed in the middle stage were wide and deep in morphology, and thick in terms of infilled sandbodies, relative to the other two stages. This result is of great significance to gas-field exploration and exploitation.

Acknowledgements This project was supported by the Natural Science Foundation of China (Grant No. 41672098) and the National 
Science and Technology Major Project (Grant No. 2016ZX05002006). We thank SINOPEC for providing data and generous technical support. We also thank Halliburton for providing the Landmark software used to interpret the seismic data. The authors are grateful to the reviewers for commenting on the original draft and improving the manuscript.

Open Access This article is distributed under the terms of the Creative Commons Attribution 4.0 International License (http://crea tivecommons.org/licenses/by/4.0/), which permits unrestricted use, distribution, and reproduction in any medium, provided you give appropriate credit to the original author(s) and the source, provide a link to the Creative Commons license, and indicate if changes were made.

\section{References}

Abrahim GMS, Nichol SL, Parker RJ, et al. Facies depositional setting, mineral maturity and sequence stratigraphy of a Holocene drowned valley, Tamaki Estuary, New Zealand. Estuar Coast Shelf Sci. 2008;79(1):133-42. https://doi.org/10.1016/j. ecss.2008.03.007.

Alqahtani FA, Johnson HD, Jackson CA, et al. Nature, origin and evolution of a Late Pleistocene incised valley-fill, Sunda Shelf, Southeast Asia. Sedimentolog. 2015;62(4):1198-232. https://doi. org/10.1111/sed.12185.

An HY. Provenance analysis and its oil-gas significance of Jurassic Shaximiao formation and Suining formation in the middle part of west Sichuan depression. Chengdu: Chengdu Univ Technol; 2011 (in Chinese).

An HY, Shi ZQ, Zhang HJ, et al. On material source of sandstone reservoir of the middle Jurassic Shaximiao formation in west Sichuan depression. J Sichuan Geol. 2011;31(1):29-33. https:// doi.org/10.3969/j.issn.1006-0995.2011.01.008 (in Chinese).

Bettis EA III, Benn DW, Hajic ER. Landscape evolution, alluvial architecture, environmental history, and the archaeological record of the Upper Mississippi River Valley. Geomorphology. 2008;101(1):362-77. https://doi.org/10.1016/j.geomorph.2008. 05.030 .

Bian CS, Zhao WZ, Wang HJ, et al. Contribution of moderate overall coal-bearing basin uplift to tight sand gas accumulation: case study of the Xujiahe Formation in the Sichuan Basin and the Upper Paleozoic in the Ordos Basin, China. Pet Sci. 2015;12(2):218-31. https://doi.org/10.1007/s12182-015-0030-0.

Breda A, Mellere D, Massari F. Facies and processes in a Gilbertdelta-filled incised valley (Pliocene of Ventimiglia, NW Italy). Sediment Geol. 2007;200(1):31-55. https://doi.org/10.1016/j. sedgeo.2007.02.008

Cao K. Late Mesozoic red beds and paleoclimate in Sichuan basin. Chengdu: Chengdu University of Technology; 2007 (in Chinese).

Catuneanu O. Principles of sequence stratigraphy. Amsterdam: Elsevier; 2006. p. 375.

Catuneanu O, Abreu V, Bhattacharya JP, et al. Towards the standardization of sequence stratigraphy. Earth Sci Rev. 2009;94(1-4):95-7. https://doi.org/10.1016/j.earscirev.2008.12. 003.

Chen ZX, Jia D, Wei GQ, et al. Meso-Cenozoic sediment transport and tectonic transition in the western Sichuan foreland basin. Geol China. 2008;35(3):472-81 (in Chinese).

Chen HD, Xu SL, Lin LB. Segmental Uplift of Longmenshan Orogen and sequence filling characteristic of western Sichuan forelandlike basin, Later Triassic. Acta Sedimentol Sin.
2011;29(4):622-30. https://doi.org/10.14027/j.cnki.cjxb.2011. 04.016 (in Chinese).

Cheng LX. Sedimentary response within orogenic movement of basin edge during late Triassic to Jurassic in eastern and northern Sichuan, China. Chengdu: Chengdu Univ Technology; 2014 (in Chinese).

Deng KL. Indosinian progressive deformation and its chronogenesis in Longmenshan structural belt. Oil Gas Geol. 2007;28(4):485-90. https://doi.org/10.11743/ogg20070407 (in Chinese).

Eoff JD. Sedimentary facies of the upper Cambrian (Furongian; Jiangshanian and Sunwaptan) Tunnel City Group, Upper Mississippi Valley: new insight on the old stormy debate. Sediment Geol. 2014;302(4):102-21. https://doi.org/10.1016/j.sedgeo. 2013.09.008.

Ferguson TW, Davis RA Jr. Post-Miocene stratigraphy and depositional environments of valley-fill sequences at the mouth of Tampa Bay, Florida. Mar Geol. 2003;200(1-4):157-70. https:// doi.org/10.1016/s0025-3227(03)00181-6.

Fustic M, Hubbard SM, Spencer R, et al. Recognition of down-valley translation in tidally influenced meandering fluvial deposits, Athabasca Oil Sands (Cretaceous), Alberta, Canada. Mar Pet Geol. 2012;29(1):219-32. https://doi.org/10.1016/j.marpetgeo. 2011.08.004.

González-Bonorino G, Colombo F, Abascal L. Architecture of an Oligocene fluvial ribbon sandstone in the Ebro Basin Northeastern Spain. Sedimentology. 2010;57(3):845-56. https://doi. org/10.1111/j.1365-3091.2009.01122.x.

Green AN. Palaeo-drainage, incised valley fills and transgressive systems tract sedimentation of the northern KwaZulu-Natal continental shelf, South Africa, SW Indian Ocean. Mar Geol. 2009;263(1):46-63. https://doi.org/10.1016/j.margeo.2009.03. 017.

Hampson GJ, Gani MR, Sahoo H, et al. Controls on large-scale patterns of fluvial sandbody distribution in alluvial to coastal plain strata: Upper Cretaceous Blackhawk Formation, Wasatch Plateau, Central Utah, USA. Sedimentology. 2012;59(7):2226-58. https://doi.org/10.1111/j.1365-3091.2012. 01342.x.

Huang J, Zhu RK, Hou DJ, et al. Influences of depositional environment and sequence stratigraphy on secondary porosity development: a case of the Xujiahe Formation clastic reservoir in the central Sichuan Basin. Pet Explor Dev. 2010;37(2):158-66.

Ielpi A. Anatomy of major coal successions: facies analysis and sequence architecture of a brown coal-bearing valley fill to lacustrine tract (Upper Valdarno Basin, Northern Apennines, Italy). Sediment Geol. 2012;265-266(1):163-81. https://doi.org/ 10.1016/j.sedgeo.2012.04.006.

Jiang ZX, Tian JJ, Chen GJ, et al. Sedimentary characteristics of the Upper Triassic in western Sichuan foreland basin. J Palaeogeogr. 2007;9(2):143-53 (in Chinese).

Jin WZ, Tang LJ, Yang KM, et al. Progress and problem of study on characters of the Longmen Mountain Thrust Belt. Geol Rev. 2008;54(1):37-46. https://doi.org/10.3321/j.issn:0371-5736. 2008.01.005 (in Chinese).

Keen-Zebert A, Tooth S, Rodnight $\mathrm{H}$, et al. Late quaternary floodplain reworking and the preservation of alluvial sedimentary archives in unconfined and confined river valleys in the eastern interior of South Africa. Geomorphology. 2013;185(3):54-66. https://doi.org/10.1016/j.geomorph.2012. 12.004 .

Lévy S, Jaboyedoff M, Locat J, et al. Erosion and channel change as factors of landslides and valley formation in Champlain Sea Clays: The Chacoura River, Quebec, Canada. Geomorphology. 2012;145-146(4):12-8. https://doi.org/10.1016/j.geomorph. 2011.09.014. 
Li DL. The distribution characteristic and difference of sedimentary system of Jurassic in the western Sichuan foreland Basin. Chengdu: Chengdu University of Technology; 2011 (in Chinese).

Li CX, Zhang GJ. Progress on high resolution sequence stratigraphy in incised paleovalley. Adv Earth Sci. 1996;11:216-20 (in Chinese).

Li JL, Xu GS, Zhu P, et al. Diagenesis and porosity evolution of Shaximiao formation in Luodai gas field of the west Sichuan. Pet Geol Exp. 2007;29(6):565-71 (in Chinese).

Li ZW, Liu SG, Lin J, et al. Structural configuration and its genetic mechanism of the West Sichuan depression in China. J Chengdu Univ Technol. 2009;36(6):645-53 (in Chinese).

Li R, Zhang D, Zhu LX. Densification of Upper Triassic Xujiahe tight sandstones, Western Sichuan China. Pet Geol Exp. 2011;33(3):274-81 (in Chinese).

Li GX, Xu SL, Chen HD, et al. Sedimentary facies and sand body distribution of the Middle Jurassic Upper Shaximiao Formation in the middle segment of western Sichuan depression. Geol China. 2012;39(1):96-105 (in Chinese).

Lin CS. Sequence and depositional architecture of sedimentary basin and process responses. Acta Sedimentol Sin. 2009;27(5):849-62 (in Chinese).

Lin CM, Li GY, Zhuo HC, et al. Sedimentary facies of incised valley fillings of the Late Quaternary in Hangzhou Bay area and shallow biogenic gas exploration. J Palaeogeogr. 2005a;7(1):12-24. https://doi.org/10.7605/gdlxb.2005.01.002 (in Chinese).

Lin CM, Zhuo HC, Gao S. Sedimentary facies and evolution in the Qiantang River incised valley, eastern China. Mar Geol. 2005b;219(4):235-59. https://doi.org/10.1016/j.margeo.2005.06. 009 . (in Chinese).

Lin $\mathrm{C}$, Li Y, Zhuo $\mathrm{H}$, et al. Features and sealing mechanism of shallow biogenic gas in incised valley fills (the Qiantang River, eastern China): a case study. Mar Petrol Geol. 2010;27(4):909-22. https://doi.org/10.1016/j.marpetgeo.2009. 11.006 (in Chinese).

Liu SG, Zhang ZJ, Huang WM, et al. Formation and destruction processes of upper Sinian oil-gas pools in the DingshanLintanchang structural belt, southeast Sichuan Basin, China. Pet Sci. 2010;7(3):289-301. https://doi.org/10.1007/s12182-0100071-3.

Liu SG, Deng B, Li ZW, et al. The texture of sedimentary basinorogenic belt system and its influence on oil/gas distribution: a case study from Sichuan basin. Acta Petrol Sin. 2011;27(3):621-35 (in Chinese).

Luo XQ, Chen L. Forming evolution of western Sichuan depression and its relation with oil and gas. Pet Geol Recover Effic. 2004;11(1):16-9 (in Chinese).

Luo XQ, Li SB. Formation of Longmen Mountain Thrust Belt and relationship with Oil and Gas Exploration. Natural Gas Industry. 2009;3(1):16-8 (in Chinese).

Luo XQ, Li SB, Zhao XK. Tectonic features and their relationship with petroleum in Longmen Mountain, western Sichuan Basin. Pet Geol Exp. 2011;33(4):384-7 (in Chinese).

Mattheus CR, Rodriguez AB, Greene DL, et al. Control of upstream variables on incised-valley dimension. J Sediment Res. 2007;77(3-4):213-24. https://doi.org/10.2110/jsr.2007.022.

Miall AD. Architectural-element analysis: a new method of facies analysis applied to fluvial deposits. Earth-Sci Rev. 1985;22(4):261-308. https://doi.org/10.2110/scn.85.19.0033.

Miall AD. the geology of fluvial deposits: sedimentary facies, basin analysis, and petroleum geology. Berlin: Springer; 1996. p. 582.

Nordfjord S, Goff JA, Austin JAJ, et al. Seismic facies of incised valley fills, New Jersey continental shelf: implications for erosion and preservation processes acting during latest
Pleistocene-Holocene transgression. J Sediment Res. 2006;76(11-12):1284-303. https://doi.org/10.2110/jsr.2006.108.

Olsen T. Sequence stratigraphy, alluvial architecture and potential reservoir heterogeneities of fluvial deposits: evidence from outcrop studies in Price Canyon, Utah (Upper Cretaceous and Lower Tertiary). Nor Pet Soc Spec Publ. 1995;5(5):75-88. https://doi.org/10.1016/s0928-8937(06)80064-0.

Paquet F, Menier D, Estournès G, et al. Buried fluvial incisions as a record of Middle-Late Miocene eustasy fall on the Armorican Shelf (Bay of Biscay, France). Mar Geol. 2010;268(1-4):137-51. https://doi.org/10.1016/j.margeo.2009. 11.002.

Posamentier HW, Vail PR. Eustatic controls on clastic deposition II. Sequence and systems tract models. In: Wilgus CK, Hastings BS, Posamentier H, Van Wagoner J, Ross CA, Kendall CGSC, editors. Sea level changes-an integrated approach. Tulsa: SEPM (Society for Sedimentary Geology) Special Publication; 1988. p. 125-54. https://doi.org/10.2110/pec.88.01.0125.

Qian LJ. Regulation of sedimentary distribution and sedimentary filling process during Middle and Lower Jurassic in Western and Northern Sichuan, China. Chengdu: Chengdu Univ Technol; 2013 (in Chinese).

Qian LJ, Chen HD, Lin LB, et al. Geochemical characteristics and environmental implications of middle Jurassic Shaximiao formation, western margin of Sichuan Basin. Acta Sedimentol Sin. 2012;30(6):1061-71.

Reynaud J, Tessier B, Proust J, et al. Architecture and sequence stratigraphy of a late Neogene incised valley at the shelf margin, southern Celtic Sea. J Sediment Res. 1999;69(2):351-64. https:// doi.org/10.1306/d42689eb-2b26-11d7-8648000102c1865d.

Rossetti DF, Santos Junior AE. Facies architecture in a tectonically influenced estuarine incised valley fill of Miocene age, northern Brazil. J S Am Earth Sci. 2004;17(4):267-84. https://doi.org/10. 1016/j.jsames.2004.08.003.

Sakai T, Fujiwara O, Kamataki T. Incised-valley-fill succession affected by rapid tectonic uplifts: an example from the uppermost Pleistocene to Holocene of the Isumi River lowland, central Boso Peninsula, Japan. Sediment Geol. 2006;185(1-2):21-39. https://doi.org/10.1016/j.sedgeo.2005.10.008.

Shanley KW, McCabe PJ. Perspectives on the sequence stratigraphy of continental strata. Am Assoc Petrol Geol Bull. 1994;78(4):544-68. https://doi.org/10.1306/bdff9258-1718$11 \mathrm{~d} 7-8645000102 \mathrm{c} 1865 \mathrm{~d}$.

Vail PR, Mitchum RM, Thompson S. Seismic stratigraphy and global changes of sea level, part four: global cycles of relative changes of sea level. Am Assoc Pet Geol Mem. 1977;26:83-98.

Van Wagoner JC, Posamentier HW, Mitchum RM, et al. An overview of the fundamentals of sequence stratigraphy and key definitions. In: Wilgus CK, Hastings BS, Kendall CGStC, Posamentier HW, Ross CA, Van Wagoner JC, editors Sea-level changes, an integrated approach eds. ). Spring: Soc. of Econ. Petrol. and Mineral. Special Publication. 1988;21(1), p. 39-45. https://doi. org/10.2110/pec.88.01.0039.

Veiga GD, Spalletti LA, Flint S. Aeolian fluvial interactions and highresolution sequence stratigraphy of a non-marine lowstand wedge: the Avile Member of the Agrio Formation (Lower Cretaceous), central Neuquén Basin, Argentina. Sediment. 2002;49(5):1001-19. https://doi.org/10.1046/j.1365-3091.2002. 00487.x.

Wang EQ, Meng QR. Discussion of the Longmen Mountain evolution in Mesozoic-Cenozoic. Science in China. 2008;38(10):1221-31 (in Chinese).

Wang YB, Xu HJ. Relations between evolution of sedimentary cycles and tectonic uplift around Sichuan basin from Jurassic to early Cretaceous. Earth Sci J China Univ Geosci. 2001;26(3):241-6. 
Wang LG, Yu FL, Deng KL. The sedimentary environment of Jurassic depression in the west of Sichuan. Pet Geol Recovery Effic. 2001;8(6):13-6 (in Chinese).

Wang W, Xu GS, Cui JW, et al. Gas reservoirs forming character in Shaximiao formation, Luodai Gas field Chuanxi Depression. Pet Geol Recovery Effic. 2007;14(5):39-41 (in Chinese).

Wang QW, Kan ZZ, Liu XH, et al. The Mesozoic sporopollen assemblage in the Sichuan basin and its significance to paleovegetation and paleoclimate. J Sichuan Geol. 2008;28(2):89-95.

Wang SC, Wang DY, Chen M, et al. Natural gas reservoir-formation condition of Shaximiao Formation in mid-band of Western Sichuan Depression. Offshore Oil. 2010;30(3):42-6.

Willis B. Architecture of fluvial-dominated valley-fill deposits in the Cretaceous Fall River Formation. Sedimentology. 1997;44(4):735-57. https://doi.org/10.1046/j.1365-3091.1997. d01-48.x.

Wilson K, Berryman K, Cochran U, et al. A Holocene incised valley infill sequence developed on a tectonically active coast: Pakarae River, New Zealand. Sediment Geol. 2007;197(3-4):333-54. https://doi.org/10.1016/j.sedgeo.2006.10.007.

Yang XP, Zhang BM, Tao SZ. Laumontite and its significance for petroleum exploration in Jurassic Shaximiao reservoir, Sichuan Basin. Pet Explor Dev. 2005;32(3):37-44.

Yang XZ, Wei NY, Wang Q, et al. Sedimentary characteristics of an ancient river channel in Zhenjiang-Jiangdu segment of Yangtze river delta. Mar Geol Quat Geol. 2010;30(5):11-8. https://doi. org/10.3724/sp.j.1140.2010.05011 (in Chinese).

Yang F, Sun Z, Zhao S. Accumulation conditions and controlling factors of Shaximiao Formation, Huilong area, Western Sichuan Depression. Pet Geol Exp. 2011;33(6):569-73 (in Chinese).

Yang YM, Yang JJ, Yang G, et al. New research progress of Jurassic tight oil in central Sichuan Basin. Pet Explor Dev. 2016;43(6):873-82. https://doi.org/10.11698/ped.2016.06.04 (in Chinese).

Ye SJ, Zhu HQ, Li R, et al. Tracing natural gas migration by integrating organic and inorganic geochemical data: a case study of the Jurassic gas fields in western Sichuan Basin, SW China. Pet Explor Dev. 2017;44(4):1-12. https://doi.org/10.11698/ped. 2017.04.00 (in Chinese).
Yong ZQ, Liu QS, Li Q. Evolution and sediment filling of western Sichuan foreland basin and their significance of hydrocarbon accumulation. Nat Gas Ind. 2008;28(2):26-9 (in Chinese).

$\mathrm{Yu}$ Y, Lin LB, Gao J. Formation mechanisms and sequence response of authigenic grain-coating chlorite: evidence from the Upper Triassic Xujiahe Formation in the southern Sichuan Basin, China. Pet Sci. 2016;13(4):657-68. https://doi.org/10.1007/ s12182-016-0125-2.

Yuan HF, Liang JJ, Gong DY, et al. Formation and evolution of Sinian oil and gas pools in typical structures, Sichuan Basin, China. Pet Sci. 2012;9(2):129-40. https://doi.org/10.1007/ s12182-012-0193-x.

Zaitlin BA, Dalrymple RW, Boyd R. The stratigraphic organization of incised-valley systems associated with relative sea-level changes. In: Boyd R, Zaitlin BA, Dalrymple R, editors. Incised valley systems-origin and sedimentary sequences, vol. 51. Tulsa: SEPM The stratigraphic organization of incised-valley systems associated with relative sea-level changes; 1994. p. 45-60. https://doi.org/10.2110/pec.94.12.0045.

Zhang $\mathrm{W}$. The evolution of the ancient lake and tight oil reservoirs formation of the early and middle Jurassic in the NE part of Central Sichuan Basin. Chengdu: Chengdu Univ Technol; 2013.

Zheng RC, Zhu RK, Zhai WL, et al. Tectonic evolution and sequence filling patterns in the western Sichuan foreland-like basin in the Upper Triassic Xujiahean period. Geol C hina. 2008;35(2):246-55 (in Chinese).

Zhu HQ. Depositional facies and reservoir characteristics research and evaluation of Shaximiao formation, middle area of western Sichuan depression. Chengdu: Chengdu University of Technology; 2009.

Zhu ZJ, Chen HD, Hu XQ, et al. Framework of sequence stratigraphy, sedimentary system and evolution of Jurassic in Western Sichuan foreland basin. Acta Sedimentol Sin. 2010;28(3):451-61 (in Chinese).

Zou CN, Gong YJ, Tao SZ, et al. Geological characteristics and accumulation mechanisms of the "continuous" tight gas reservoirs of the Xu2 Member in the middle south transition region, Sichuan Basin, China. Pet Sci. 2013;10(2):171-82. https://doi. org/10.1007/s12182-013-0264-7. 